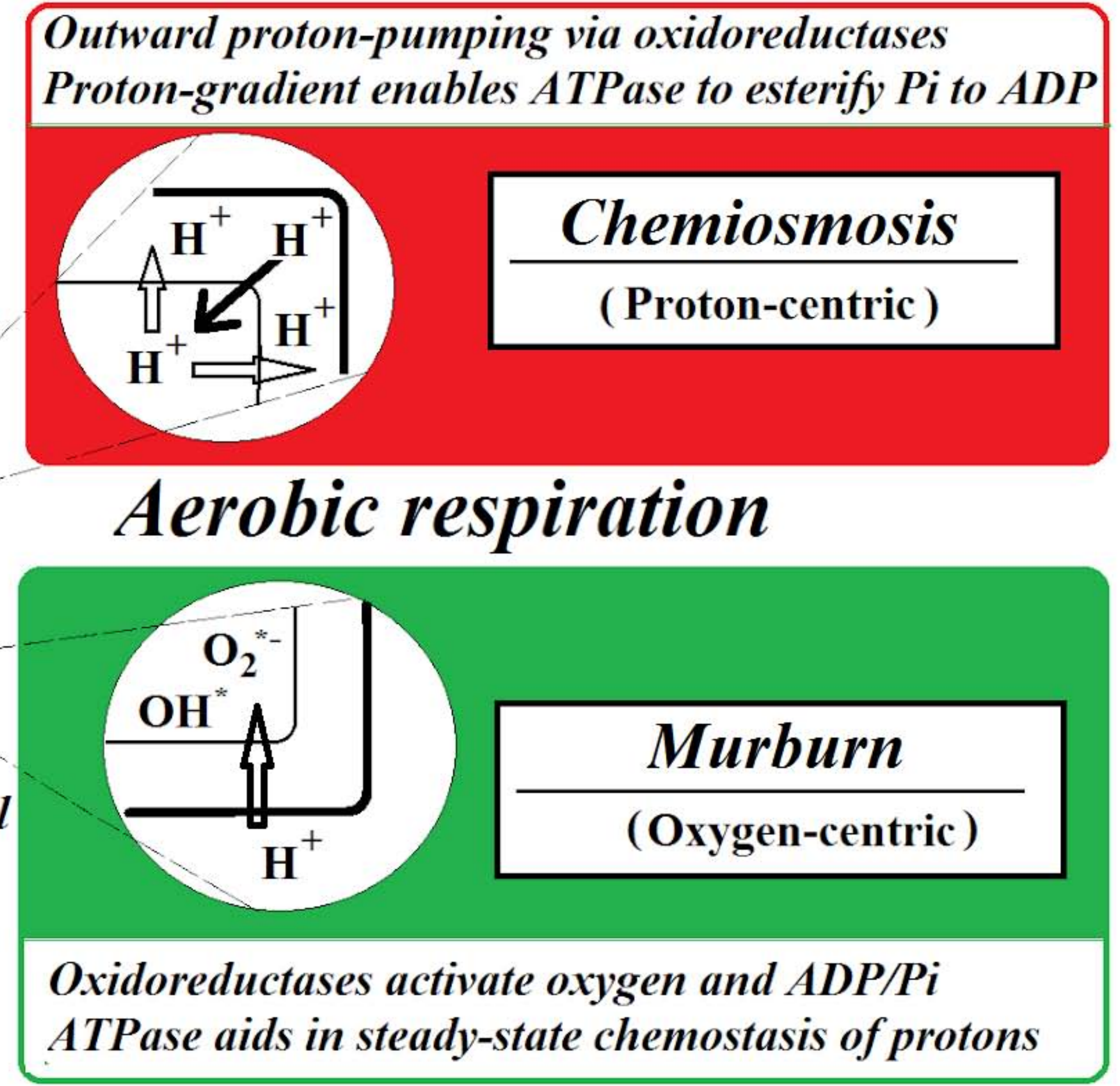




\title{
Murburn precepts for aerobic respiration and homeostasis
}

\author{
Kelath Murali Manoj ${ }^{{ }^{*}} \&$ N. M. Bazhin ${ }^{2 *}$ \\ *Corresponding author, ${ }^{1}$ Satyamjayatu: The Science \& Ethics Foundation, \\ Snehatheeram, Kulappully, Shoranur-2 (PO), Kerala, India-679122. \\ murman@satyamjayatu.com \\ ${ }^{*}$ Corresponding author, ${ }^{2}$ Institute of Chemical Kinetics and Combustion \\ Russian Academy of Sciences, St. Institutskaya 3, 630090 Novosibirsk, Russia. \\ bazhin8999@kinetics.nsc.ru
}

\begin{abstract}
Transformed Gibbs free energy values of respiratory reactions are calculated to address the spontaneity, selectivity, control, and efficiency of oxidative phosphorylation. We present tangible explanations for ubiquinone's role in mitochondria, $\mathrm{HCN}>\mathrm{H}_{2} \mathrm{~S}$ order of cellular toxicity in aerobes and why oxygen inhibits anaerobes. Our data/arguments highlight the significance of proton deficiency in NADH/mitochondria and link the 'oxygen $\rightarrow$ ROS (reactive oxygen species) $\rightarrow$ water' metabolic pathway to the macroscopic physiologies of ATP-synthesis, trans-membrane potential, thermogenesis, and homeostasis. This 'murburn perspective' affords a probabilistically and thermodynamically viable precept for the origin and evolution of the 'working logic' of oxygen-centric life.
\end{abstract}

Significance: In the last few years, we have successfully dissected the Mitchellian chemiosmotic explanation for mitochondrial oxidative phosphorylation (cellular respiration) and proposed a new mechanistic paradigm in lieu, called murburn concept. This manuscript provides the chemical equations and thermodynamic foundations for the new oxygen-centric metabolic paradigm for cellular respiration and homeostasis. The findings are of a Kuhnian "paradigm shift" nature, and poised to impact pursuits in biology/medicine in an unprecedented way.

Keywords: thermodynamics, mitochondria, aerobic respiration, murburn, kinetics, selectivity, homeostasis, metabolism, physiology, evolution, transmembrane potential 
Contextual background: Unraveling the mechanism of aerobic respiration (mitochondrial oxidative phosphorylation, mOxPhos), the fundamental powering routine of oxygen-centric life, has been a daunting challenge. As evident from global recognitions, popular textbooks, experts' reviews and research articles in reputed journals, the explicatory paradigm is protoncentric; comprising the concepts of David Keilin's Electron transport/transfer chain (ETC), Peter Mitchell's Proton-pumps / Chemiosmosis (proton motive force, pmf) and Paul Boyer's Rotary ATP synthesis (1-14). Based on the founding ideas above, the extant perception is anagrammed $\boldsymbol{R} \boldsymbol{C P E}$ or $\boldsymbol{C R A S}$ (chemiosmotic rotary ATP synthesis) model. In 2017, updated data on mitochondrial architecture / protein complexes' structures (7-10) were assessed in the light of insights gained from our research on simpler heme-flavin enzyme systems (15-23), enabling us to challenge the CRAS paradigm of mOxPhos and propose a novel explanatory model (24-31) based in murburn concept. The murburn explanation invokes a ubiquitous "molecule-unbound ion-radical” interactive scheme (32) and proposes that the catalytic role of diffusible reactive (oxygen) species [DRS/DROS/ROS, hitherto deemed wasteful/toxic agents] are harnessed in some metabolic electron/moiety transfers. The murburn model of mOxPhos is strongly supported by the fact that DROS enables ATP synthesis both in vitro $(27,29)$ and in situ [within mitochondria (33) and chloroplasts (34)]. Also, our arguments (2431) against the extant paradigm of mOxPhos are corroborated by other researchers' reports demonstrating the 'dispensability' of Complex V in both prokaryotic E. coli (35) and eukaryotic Plasmodium (36) systems. Disregarding such arguments and developments (24$32,37)$, the CRAS model continues to be advocated for mitochondrial physiology $(10-14,37)$. Some peers vocally expressed concerns on how the murburn scheme could be 'selective', with catalytic role for diffusible radicals. Therefore, the two models of aerobic respiration are theoretically assessed herein for thermodynamic efficiency and overall viability. Starting from the usual Gibbs function representations, Bazhin had recently calculated the transformed Gibbs energy values of formation $\left(\Delta_{\mathrm{f}} \mathrm{G}^{\prime{ }^{\prime}}\right.$ aq $)$ of some relevant molecules/ions/radicals in aqueous phase under standard conditions (at $\mathrm{T}=298 \mathrm{~K}, \mathrm{pH}=7$ and $[I]=250 \mathrm{mM}$ (38), as given in Table A, Supplementary Information). Herein, further relevant entities' transformed Gibbs energy of formation $\left(\Delta_{\mathrm{f}} G^{\prime \prime}{ }_{\text {aq }}\right)$ and transformed energy values for the overall mOxPhos reactions $\left(\Delta_{\mathrm{r}} G^{\prime 0}\right.$ aq $)$ were calculated from the reactants' and products' $\Delta_{\mathrm{f}} G^{\prime 0}$ aq values by the relation:

$$
\Delta_{\mathrm{r}} G^{\prime 0}{ }_{\text {aq }}=\sum_{\text {products }} v_{i} \Delta_{\mathrm{f}} G^{\prime 0}{ }_{\mathrm{i}, \mathrm{aq}}-\sum_{\text {initials }} v_{\mathrm{j}} \Delta_{\mathrm{f}} G^{\mathrm{\prime O}}{ }_{\mathrm{j}, \mathrm{aq}}
$$


Gist of the murburn model for mOxPhos: As per the murburn scheme shown in Table 1 and Figure 1, the reaction system activates oxygen, enables charge separation and facilitates the spontaneous formation of superoxide. Spin-locks and caged-radicals issues are overcome around the inner mitochondrial membrane (IMM, packed with quinones) with the flavin/Fe containing Complexes I \& II. The highly facile $\mathrm{NADH}-\mathrm{O}_{2}$ one-electron transfer (equations 2 \& 3 of Table $1, K_{e q}=10^{71}$ to $10^{76}$ ) or the incomplete reduction of oxygen to peroxide (equation 1 of Table $1, K_{e q}=10^{102}$ ) and the intermediacy of oxygen-centered radicals ensure diffusion-level kinetics (28), and several such parallel reactions can afford overall pseudofirst order rates of $\sim 10^{3} \mathrm{~s}^{-1}$. The stabilization and modulation of DROS around the IMMmatrix interface or murzone (24) enables the utilization of the radicals' phosphorylation potential in the 'aprotic' milieu. The efficiency of murburn reactions is enhanced by the multiple heme/flavin/Fe-S redox centers within matrix-ward protruding proteins (Complexes I thru IV) bearing ADP-binding sites and the high ambient concentration of inorganic phosphate $\left(\sim 10^{-2} \mathrm{M}\right)$. The murburn reactions are bimolecular, with viable equilibrium/kinetic constants (Table 1, and also see Table B, Supplementary Information for more details of calculation). The decentralized water formation within the matrix and its outward osmotic/turgor (along with the ATP/ADP exchange via porters) movement forms the fundamental 'thermodynamic pull' logic of murburn concept. For example- equation 7 of Table 1 has at least 11 reactants/solutes whereas only 6 products (discounting water, the solvent) are formed. Therefore, the forward reaction is instantaneously 'tugged on' by presenting reactants $\left(\mathrm{NADH}+\mathrm{O}_{2}\right)$ and the constitutive loss of redox equivalents is minimal in the absence of ADP+Pi. Complexes III and IV serve as 'turbo agents', recycling the reduced quinones (CoQ/Q) / cytochrome $c$ (cyt. $c$ ) and peroxide, to reset a one-electron reaction within the matrix side. The utilization of peroxide via Complex IV is a major drive because water formation is facile with hydroxyl radical's attack on $\mathrm{ADP}+\mathrm{Pi}$. Thus, cells need oxygen to form the catalytic DROS, which, along with cytoplasmic protons, yield mitochondrial water+ATP/heat. Such a 'hearth or nuclear reactor' type logic of murburn-mOxPhos scheme (32) is served with tethered (heme-Fe or Fe-S centers) or free metal ions $\left(\mathrm{Mg}^{2+}\right)$, cyt. $c$ and CoQ. Sourced water provides protons for the mOxPhos reactions and the outward osmotic movement of water results in homeostasis. Thus, the chemical reaction equilibrium of oxygen-DROS-water and the physical dynamics of water (dielectrics/solvation, trans-phase migration and transport of metabolites) are the key 'engine-machine logic' of cellular life (Figure 1). Therefore, murburn model of mOxPhos points out that cells exploit the electronic, 
associative-dissociative, and colligative properties of the heterogenous oxygen-water system to integrate metabolic (ATP synthesis) and physiological (homeostasis/thermogenesis) processes. The DROS generated in mitochondria (by Complexes I-IV) strongly correlate to $\mathrm{NADH} / \mathrm{O}_{2}$ presented, ATP-synthesized, heat produced, and trans-membrane potential (TMP) observed $(26-28,39,40)$. If the DROS are not utilized for ATP-synthesis (an endergonic reaction), they react among themselves, whereby the redox equivalents are diverted into heat+water formation, which explains mitochondrial thermogenesis (26). The transient formation of negatively charged entities around the IMM explains the origin of steady-state TMP, which could be dissipated by the activity of anion transporting uncoupling proteins (UCP, Figure 1) (26).

Thermodynamics of murburn reactions: As shown in Table 1 \& Figure 1 [and in the light of data/arguments presented earlier (24-32,37)], murburn scheme better reconciles with the reaction milieu, catalytic components and mitochondrial architecture. Statistical/stochastic bimolecular interactions or diffusion limited collisions determine reaction outcomes within the mitochondrial pot, and there are little deterministic pathways for electron/group transfer. Unlike the usual two-electron metabolic reactions of predictable/defined stoichiometry, the murburn scheme is primarily a mixture of several one-electron reactions (28). Therefore, $\mathrm{P} / \mathrm{O}$ values are variable, non-integral and most of the times, non-optimal values are obtained. This is because a given reaction cascade could get terminated at any instant, and the efficiency depends on the fine-tuning of the reaction microenvironment. The maximal efficiency is obtained only if every single reaction initiated within the mitochondrial pot 'hits the jackpot' (the maximum number of energetically feasible reactions), which is statistically improbable. The mitochondrial reaction strategy evolved to keep supplying protons in a dynamic manner to enable $\mathrm{O}-\mathrm{H}$ bond formations in the reactive intermediates/products (Table 2), thereby tugging the oxygen-superoxide equilibrium to the right, towards water/peroxide formation. Since forming $\mathrm{ATP}+\mathrm{H}_{2} \mathrm{O} / \mathrm{H}_{2} \mathrm{O}_{2}$ requires cytoplasmic protons and the latter affect kinetics (26) and energetics in milieu (Table 2), the earlier observed effects derived upon lowering extra-organelle $\mathrm{pH}$ are reasoned [as seen in Jagendorf experiment and equilibrium driven ATP synthesis by Complex V (25-28)]. Facile one-electron cycling in steady state is achieved (Table 2) by the fact that partially oxidized $\mathrm{NADH} / \mathrm{FADH}_{2}$ and semiquinone have significantly lower transformed Gibbs energy terms of formation relative to the fully oxidized/reduced nucleotides and quinones respectively (Table A, Supplementary Information). The CRAS model seeks a complete oxidation of reduced nucleotides without 
the intermediacy of DROS (Table 1), also erroneously discounting the energetic contribution of protons in NADH oxidation under steady state. With the murburn perspective, NADH gives significantly higher efficiency compared to succinate (Table 1), explaining the evolutionary utility of the proton-deficiency in NADH. It can be noted that with Complex I + $\mathrm{NADH}$, both oxidative and peroxidative phosphorylation is viable whereas with Complex II + succinate, only the latter is predominant. The final yield also depends on the ATP utilization and proton availability dynamics regulated by the activity of Complex V. There could also be a steady background loss of DROS loss through thermogenesis route. Yet, the higher efficiency murburn model explains the maximum yield of 3.5 ATP experimentally noted for $\mathrm{NADH}(41,42)$ (i.e. the $\mathrm{P} / \mathrm{O}$ ratio), which cannot be reasoned by the extant paradigm (as it vouches for lower efficiency of 2.5 ATP per NADH) (43). Also, the extant explanation does not afford any chemical connectivity of oxidative and phosphorylation reactions. With the controlled and incomplete oxidation of reduced nucleotides via the murburn model $\left[\left[\left(\mathrm{NADH}+\mathrm{H}^{+}\right) / \mathrm{FADH}_{2}+\mathrm{O}_{2}+\mathrm{ADPOH}+\mathrm{POH} \rightarrow \mathrm{NAD}{ }^{+} / \mathrm{FAD}+\mathrm{ATP}+\mathrm{H}_{2} \mathrm{O}\right.\right.$ $\left.+\mathrm{H}_{2} \mathrm{O}_{2}\right]$ ], the viable chemical coupling gives higher chemical energetic yields (Table 1 ). In this regard, blocking Complex I activity with rotenone to determine mitochondrial ATP yields of succinate may be a misplaced approach. This is because Krebs cycle generates $\mathrm{NADH}$ even with succinate (via malate dehydrogenase) and the concept that "three distinct steps of phosphorylations existed within ETC (NADH $\rightarrow$ Complex I $\Rightarrow$ CoQ $\rightarrow$ Complex III $\Rightarrow$ cyt. $c \rightarrow$ Complex IV $\left.\Rightarrow \mathrm{O}_{2}\right)$ " is an inaccurate perspective $(27,28)$.

Quinones and the mitochondrial membrane: The CRAS paradigm seeks a repeated orchestration of the practically improbable but 'vitally deterministic' multi-molecular Qcycle at Complex III. The structure-function correlations of proteins and thermodynamics/kinetics of the proposed Q-cycle reactions are untenable (25-28), as the yield of the reaction at Complex III would be inadequate for 'pumping' of more than one proton per molecule of $\mathrm{CoQH}_{2}$ (reaction $\mathrm{B}$, Table 2). Further, since the mitochondria are practically aprotic, for availing protons, an additional $79.1 \mathrm{~kJ} / \mathrm{mol}$ would be required for heterolysis of water (Reaction 13, Table 2), which makes the extant paradigm thermodynamically unviable. In stark contrast, the murburn model sees quinones as a DROS quencher and modulator, as shown in reactions 3 to 10 of Table 2. The new model does not need CoQ to relay electrons via a chartered mobility across the membrane. While the CRAS model does not explain the unusually long chain lengths of isoprenyl units ranging from 6 to 10 (which, together with the substituted $s p^{2}$ carbons makes them unsuitable for mobility 
roles), murburn scheme sees this as a ploy to enhance the packing/distribution efficiency of CoQ within the inner membrane. This attribute enables CoQ to capture any superoxide escaping outward through the membrane, reorient with charged or polar phenyl group at the interface. Thus, reduced CoQ could give its electron to oxygen molecules coming inward, thereby retaining DROS within the matrix. By virtue of the lower $\Delta_{\mathrm{f}} G^{\prime}{ }_{\text {aq }}$ of its one-electron reduced (semiquinone) species, CoQ is a one or two electron dynamic sink in the membrane and Complex III recycles the electrons lost to CoQ by resetting a one-electron paradigm across the membrane. Also, by serving as an efficient two-electron sink in the membrane phase, CoQ enables sufficient thermodynamic drive for charge separation.

Selectivity and evolutionary considerations: All vital molecules have contextual significance in life processes. For example- though carotenoid vitamins are essential for vision, they are known mitochondrial toxins (44). Similarly, DROS also have contextual roles. The favorable outcomes of DR(O)S (e.g. nitric oxide, a key molecular messenger) are also evident in literature $(45,46)$. If DRS could serve as crucial messengers (relaying message across space and time within a cell), it is only natural to state that they could also serve to relay electrons and moieties at certain loci and instants. We have shown that selective/specific reactions can also be fashioned by diffusible species, and such processes can also give activations/inhibitions in redox enzyme mediated electron/group transfers (16-23). In mitochondria, the high concentration and discretized localization of DROS-generating and stabilizing one-electron redox centers enables 'phosphate-transfers' by DROS, as shown in Table 3, and which is quite similar to the mechanism of chlorinations and xenobiotic hydroxylations demonstrated in our earlier works $(16,23)$. The bulbous flavin/heme/Fe-S proteins protrude from the lipid membrane (with densely packed CoQ) and the proteins' multiple ADP-binding sites aid in the catalytic utilization of DROS within the murzone. CoQ/cyt. $c$ in the membrane/inter-membrane space (IMS) recycle the ROS via a one-electron scheme back into the matrix via Complex III/IV. The matrix-ward projections of Complexes I \& II (with a somewhat favorable redox potential gradation) ensure that electrons in superoxide produced at the flavins go to the membrane along a probabilistic route and sink within the CoQ at the membrane. If Complex III merely served to relay electrons to cyt. $c$, it would mandate that the surface residues of the latter protein is conserved for effective docking with both Complexes III and IV. While the surface topology of cyt. $c$ varies across organisms, the ligand sphere of heme is conserved; which supports the murburn model. Only 
when the DROS molecules venture farther from the IBM/IMM (into free aqueous milieu) do the soluble enzymes like catalase and superoxide dismutase consume them, as we have amply demonstrated in microsomal xenobiotic metabolism (18-23). Over time, some damage is done to the membrane machinery and dissolved proteins but most of these are taken care of by the house-keeping systems such as glutathione peroxidase or ubiquitin. The cumulative damage (leading to senescence and natural death) is a cost that life must pay for the facile and highly "responsive” chemical energy currency generation logic. In free solution, DROS also attack activated carbon centers of keto-acids like pyruvate, converting it to acetate, enabling fundamental mainstream metabolic rerouting in mammals (47). Efficient internal competing reactions (Table 3 and Table B, Supplementary Information) scavenge DROS when they are in high concentrations, which is an essential internal control mechanistic feature of the murburn scheme that enables the utilization of DROS at optimal ranges. (Coupling of these reactions with the energetically unfavorable reactions that need radical quenching could give more efficiency of phosphorylation.) Non-optimal ranges of oxygen would therefore disrupt the equilibriums, explaining hypoxic/hyperoxic pathophysiology. The attack on inaccessible and unactivated carbon atoms (that require more than 1 Volt) seen in several biological metabolites cannot be explained mechanistically by active-site intermediates and only diffusible radicals fit the bill. The probability that superoxide and hydroxyl radicals react with phosphate ions or between the DROS themselves (as given in Table 2) would be more than the chances of their reaction with $\mathrm{C} / \mathrm{N}$ centered molecules. Further, the energy terms of formation of such radicals are significantly higher (Table A in Supplementary Information) and thus, ATP synthesis reaction (which occurs via multiple routes, Table 3) would be more favorable than the side-reactions. The differences in the values of $\Delta_{\mathrm{r}} G^{\prime 0}$ aq , concentrationbased stabilization with dynamic partitioning, intrinsic spin locks and thermodynamic pull, local dielectrics, and limiting proton supply enable selectivity and directional controls inherent within the reaction system. Thus, when DROS is released in a sustained manner (some stay tethered on to the heme-centers or get moderated through the Fe-S centers), TMP seldom goes above $\sim-200 \mathrm{mV}$, which is the perceived limit of phospholipid dielectrics.

The thermodynamically and kinetically untenable CRAS proposal's 'gambit' logic does not align well with the principles of molecular/cellular evolution $(27,28)$. With the murburn perspective, the double membrane structure and IMM's invaginations (diverse types of cristae) are seen as a mechanism to enable a higher surface area to load greater amounts of 
redox proteins and lower trans-membrane free-flux of protons (except via Complex V). While the murburn model is compatible with the independent functioning of each protein or complex, it also explains the evolution of supercomplexes (respirasomes) as a means to optimize DROS dynamics (27-28). Murburn signifies a 'mured (closed) burning' and burning is noted even within anoxic conditions. Nitrogen or sulfur moiety/ion-based ions/radicals in anaerobic systems could serve coupling roles in the archaic anaerobes. But since oxygen is a small diatomic diradical gas that has direct equilibrium with water and its dissociation products, its availability and turnover is more efficient. Also, the major respiratory product of $\mathrm{CO}_{2}$ is a gas that could be easily 'exhausted'. These facile facets explain the abundance of aerobic life forms and their quick response times. If life evolved from disorder or chaos, it must have the signature of chaos within and also the inherent modality to deal with that chaos; and murburn scheme captures this essence. Quite like the deleterious effects, DROS also have beneficiary windows within the contexts of space, time and amounts (20-22,2432,44-47). It can also be envisaged that affinity/binding-based reactions within a topologically complementary active site would not have been possible at the inception of life, and were optimizations resulting at later times. Further, it can be projected that DR(O)Scentric life would have evolved in lipid encapsulated micro-dimensioned droplets because these realms better stabilize the essential radicals (owing to limited 'free-proton' availability). Phospholipids (with anionic polar heads to repel superoxide) became the preponderant choice for embedding the redox proteins because of a reduced number of functionalized groups (contrary to what is seen in carbohydrates, proteins or nucleic acids) that would have been otherwise subjected to attack. The statistical/stochastic murburn reaction logic could thus usher in 'a limiting order within chaos' and is therefore, conducive with evolutionary and probabilistic principles. The enhanced mobility of oxygen, its reactivity and internal spinlocking system (singlet and triplet states), and the facile removability of metabolites afford quick response times with respect to environmental stimuli. Murburn-centered life could also afford significant variations in genetic traits, owing to inherent mutability and epigenetic modifications induced with DROS. On the macroscopic scales, the disruption of mitochondrial membranes leaches cyt. $c$ out, which triggers apoptosis. Within the Darwinian scheme, at instances that when such cells don't undergo apoptosis, the organism could not live on, or the outcomes gave mutant (or cancerous) cells with altered activity. Also, the fact that cells/organisms with high metabolic rates have lower lifetimes underlines the physiological relevance of DROS. Demonstration of a rotary ability to the $F_{0}$ module's ATPase activity does not confirm a physiological rotary $F_{0} F_{1}$ ATP-synthase attribute to 
Complex V. The functionality attributed to this Complex in the murburn model (proton/cation-inletting role) is more amenable, as it could have evolved at a later phase in the evolutionary time scale, to enhance the efficiency of mOxPhos. Else, Complex V would surely qualify for Michael Behe's anti-evolutionary logic of "irreducible complexity". In the new perspective, Complex V's conserved 'DELSEED' loop could be a proton-relay facet, to serve its steady-state equilibration role. The new attribution is also supported by the fact that Complex V has higher affinity for ATP and oligomycin/venturicidin (proton-channel disruptors binding $F_{0}$ subunit) deleteriously affect Complex $V$ mediated outcomes (4-7). FCCP (trifluoromethoxy carbonylcyanide phenylhyrdazone) and DNP (dinitrophenol) are known interfacial DROS/proton modulators and murburn scheme explains the outcomes with such uncouplers $(11,14,19,31)$. Effects of respiratory poisons like rotenone and retinoic acid are also adequately explained by the murburn scheme (27-29).

The curious effects of some hemeFe active site ligands like azide and cyanide (CN) remained a long-standing conundrum (inexplicable with the extant paradigm), which we recently solved by the application of murburn reaction logic $(20,21,24,25,27-29,48-50)$. Table 4 shows the 'thermodynamic analyses' of murburn reactions involved in $\mathrm{HCN} / \mathrm{H}_{2} \mathrm{~S}$ inhibition. It is now evident why $\mathrm{HCN}$ (which is a weaker ligand of hemeFe than $\mathrm{H}_{2} \mathrm{~S}$ ) is a more potent toxic agent than $\mathrm{H}_{2} \mathrm{~S}(29,50,51)$. The initial ROS $+\mathrm{CN}$ reaction cycle has ${\Delta_{\mathrm{r}}} G^{\prime 0}$ aq value of $\sim$ 197 to $-225 \mathrm{~kJ} / \mathrm{mol}$ and the best value for ROS attack on Pi is only $-32 \mathrm{~kJ} / \mathrm{mol}$ (as shown in Table 2). Therefore, $K_{\mathrm{eq}}$ for CN mediated DROS diversion is minimally thirty orders higher than the initial favorable step of murburn model of ATP synthesis. In contrast, the ROS $+\mathrm{H}_{2} \mathrm{~S}$ reaction shows significantly lesser $\Delta_{\mathrm{r}} G^{\prime 0}$ aq than the $\mathrm{CN}$ reaction. The variable valences of $\mathrm{S}$ and the two protons contained within enable highly facilitated oxidation cascades (as shown in reactions 6 thru 9, Table 4). These 'sink' electrons as pairs (via reaction of the intermediates with molecular oxygen and ROS), forming polar products like $\mathrm{SO}_{2}$ or $\mathrm{SO}_{3}$ (and sulfate ions thereafter, not shown). However, these reactions still leave behind DROS in milieu, which could enable some background ATP synthesis. In short, the non-competitive inhibitor of $\mathrm{H}_{2} \mathrm{~S}$ (which is also a non-competitive inhibitor like HCN) is not as toxic as HCN because cyanide anion is regenerated in steady state (to serve as an efficient recyclable catalyst via highly facile radical reactions) whereas $\mathrm{H}_{2} \mathrm{~S}$ also gets metabolized efficiently. The scheme depicted in Table 4 also explains why oxygen is inhibitory to anaerobic sulfur bacteria because the physiologically vital reverse reaction in these microbes (from sulfate to 
the voidable gas of $\mathrm{H}_{2} \mathrm{~S}$ ) would be thwarted by oxygen (which would drive the equilibrium back towards sulfate), thereby scuttling the 'working logic' of such cells. However, we could expect some minimal ATP synthesis even in these systems under mildly oxic/aerobic conditions, if the diffusible radical murburn paradigm was an evolutionary principle. The fact that presenting small amounts of oxygen even to sulfate reducing bacteria (several species of the genus Desulfovibrio) led to ATP synthesis (52) ratifies our projections, vouching for a radical mode of phosphorylation in these organisms too. On the other hand, if electron transfers occurred in respiration only through Marcus outer sphere mechanism following high affinity binding processes with overall two-electron reaction schemes (4-7), we cannot explain such outcomes. Within the murburn purview, we can reason out the evolutionary similarities between the respiratory enzymes like NO reductase of anaerobes and Complex IV of aerobes.

Summations \& Projections: Herein, we addressed queries on the powering logic of aerobic respiration, such as- (a) How is murburn scheme a better explanation for mitochondrial architecture, generation of transmembrane potential (TMP), membrane proteins'/cofactors' structure/assembly, overall reaction rates/scalability and the roles of NADH, oxygen, proton and water? (b) Why is murburn scheme favored on probability and evolutionary logic? (c) How can DR(O)S be the elixir of life when anaerobic microbes exist and when DR(O)S are linked with oxidative stress, apoptosis, ageing, auto-immune disorders, cancer, several other diseases and pathophysiologies? (d) If ROS are essential, why have catalase and superoxide dismutase in cells? (e) How does murburn scheme of aerobic respiration explain the efficiency of ATP generation? (f) How can ROS be selective and why don't they attack dissolved proteins' or membrane lipids' moieties? We unraveled the logic of inherent selectivity of murburn scheme, also pointing to the significance of proton deficiency in $\mathrm{NADH} /$ mitochondria. Owing to low-activation energy barriers for radical reactions and negative Gibbs free energy change for the proposed reactions, the one-electron murburn scheme is kinetically and energetically viable. The murburn model is also supported by the fact that there are $>30$ one-electron agents within the mitochondrial respiratory cascade/relay and the fact that one-electron reduced species of NAD, FMN and FAD have lower $\Delta_{\mathrm{f}} G^{\prime}{ }^{\circ}$ aq than their fully oxidized or reduced respective counterparts (Table A, Supplementary Information). The murburn cascade of CN-toxicity is a more physiologically tenable explanation (29) because- (i) it is practically demonstrable and theoretically viable at nM 
concentrations of enzyme and micromolar concentrations of $\mathrm{CN}$, regimes wherein $\mathrm{CN}$ binding can be ruled out; (ii) it is an irreversible reaction, which cannot be undone by the fast oxygen-binding equilibriums; (iii) it is a non-competitive (out of the active site, in milieu) logic, which agrees with the commonality of such inhibitions observed across other heme enzymes; and (iv) it is a kinetically and thermodynamically sound mechanism with welldefined reactions. Therefore, murburn perspective correctly predicts the physiological toxicity in the order of $\mathrm{HCN}>\mathrm{H}_{2} \mathrm{~S}>\mathrm{CO}(48,51)$, quite opposite to the misplaced predictions of the extant hemeFe binding-based explicatory paradigm (29). Murburn concept is an evidence-based explanation grounded in probability, thermodynamics/kinetics and reaction chemistry, which satisfactorily connects chemico-physical events and structure-function correlations within the mitochondria (Figure 1). Oxygen diffuses 'freely' into the mitochondria to interact with several one-electron reaction centers maintaining a steady-state dynamics of DROS. The water+ATP formed exit via porins+porters, thereafter washing away polar wastes from the cytoplasm with it. Protons enter mitochondria non-specifically through the membranes (to be taken up by CoQ/cyt. c) and via Complex V (for phosphorylation and thermogenesis). Thus, core aspects of cellular metabolism, thermogenesis and homeostatic physiology are linked, making murburn concept a primordial directive logic of life.

Using ${ }_{18} \mathrm{O}$ labeled inorganic phosphate and water, Mildred Cohn had originally postulated that "there are at least two kinetically distinguishable steps in the formation of ATP from inorganic phosphate coupled to electron transport” (53). Her proposal and results are explained by the murburn scheme of radical reactions (Table 3), in conjunction with the spontaneous ATP hydrolysis by Complex V (and other agents). The pioneering works by Galina Mironova demonstrating peroxidative ADP-phosphorylation (and electron transfer) in mitochondria (54) and Kathleen Mailer showing oxidative phosphorylation of ADP by in situ generation of superoxide (33) also support the murburn model. Recent revelations of salmon's cnidarian parasite Henneguya salminicola showing no mitochondrial genes for the purported "proton-pumping membrane complexes" [i.e. absence of Complexes I, III \& IV and the presence of only Complexes II \& V, as seen from Figure 3 of the paper by Yahalomi et al. (55)] strongly support a peroxidative phosphorylation scheme (a subset of the murburn model) within this hypoxic living system. Therefore, the murburn model offers scope for understanding the metabolic evolution from the negative redox potentials ambiance of relatively slower anoxic+anaerobic systems [such as sulfate reducing prokaryotes (56)] transitioning to hypoxic conditions (with primarily peroxidative phosphorylation) and 
culminating in the immensely faster and fully aerobic routine at higher oxygen pressures (across the spectrum of -400 to $+800 \mathrm{mV}$, with oxidative + peroxidative phosphorylation). Also, the experiments predicted in our earlier communications $(27,28)$ stand to further validate our theory. It is envisaged that with greater outreach and acceptance of murburn concept in research community, a paradigm shift in the understanding of biology and practice of medicine would ensue in the areas of stimuli/signal transductions and networks, epigenesis, cybernetics, ageing, and pathophysiologies (like cancer, arthritis, diabetes, etc.) (32). Particularly, the mechanism of important metabolic routines like oxygenic photophosphorylation $(57,58)$ and $\mathrm{N}_{2} / \mathrm{CO}_{2}$ fixation should be immediately revisited because these pathways are also known to be inhibited by the murburn-active principles of CN/azide $(59,60)$. To conclude, our work cautions against research endeavors that portray DROS as mere villains in normal or pathological states. DROS are the elixirs of life that network various metabolic and physiological routines, and their obligatory requirement in aerobic respiration and xenobiotic metabolism is established beyond reasonable doubts now.

Acknowledgments \& Disclosures: KMM acknowledges Vivian David Jacob for drawing Figure 1 and would like to document sparring email interactions on the subject with faculty of University of Illinois, Urbana-Champaign. The research was powered by Satyamjayatu: The Science \& Ethics Foundation. KMM conceived the problems, equations/explanations and wrote the paper. NMB calculated the thermodynamic constants and provided crucial inputs.

\section{References}

1. P. Mitchell, Coupling of phosphorylation to electron and hydrogen transfer by a chemi-osmotic type of mechanism. Nature 191, 144-148 (1961).

2. P. Mitchell, David Keilin's respiratory chain concept and its chemiosmotic consequences. Nobel Lecture. https://www.nobelprize.org/uploads/2018/06/mitchell-lecture.pdf (1978).

3. P. D. Boyer, Energy, life, and ATP. Nobel Lecture. https://www.nobelprize.org/uploads/2018/06/boyerlecture.pdf (1997).

4. B. Alberts, A. Johnson, J. Lewis, M. Raff, K. Roberts, P. Walter, Molecular Biology of the Cell $4^{\text {th }}$ edn. (Garland Science, 2002).

5. J. M. Berg, J. L. Tymoczko, L. Stryer, Biochemistry $5^{\text {th }}$ edn. (W H Freeman, 2002).

6. D. L. Nelson, M. C. Cox, Lehninger: Principles of Biochemistry $4^{\text {th }}$ edn. (W H Freeman, 2004).

7. D. Voet, J. G. Voet, Biochemistry $4^{\text {th }}$ edn. (Wiley, 2011).

8. L. A. Sazanov, A giant molecular proton pump: structure and mechanism of respiratory complex I. Nat. Rev. Mol. Cell Biol. 16, 375-388 (2015).

9. W. Kuhlbrandt, Structure and function of mitochondrial membrane protein complexes. BMC Biol. 13, 89 (2015).

10. J. B. Spinelli, M. C. Haigis, The multifaceted contributions of mitochondria to cellular metabolism. Nat. Cell. Biol. 20, 745-54 (2018).

11. M. Momcilovic, et al. In vivo imaging of mitochondrial membrane potential in non-small-cell lung cancer. Nature 575, 380-384 (2019).

12. B. J. Murphy, et al., Rotary substates of mitochondrial ATP synthase reveal the basis of flexible F1-Fo coupling. Science 364, eaaw9128 (2019). 
13. S. Viola, et al. Probing the electric field across thylakoid membranes in cyanobacteria. Proc. Natl. Acad. Sci. USA 116, 21900-21906 (2019).

14. D. M. Wolf, et al. Individual cristae within the same mitochondrion display different membrane potentials and are functionally independent. EMBO J. 38, e101056 (2019).

15. K. M. Manoj, L. P. Hager, Utilization of peroxide and its relevance in oxygen insertion reactions catalyzed by chloroperoxidase. Biochim. Biophys. Acta 1547, 408-417 (2001).

16. K. M. Manoj, Chlorinations catalyzed by chloroperoxidase occur via diffusible intermediate(s) and the reaction components play multiple roles in the overall process. Biochim. Biophys. Acta 1764, 1325-1339 (2006).

17. K. M. Manoj, L. P. Hager, Chloroperoxidase, a Janus enzyme. Biochemistry 47, 2997-3003 (2008).

18. K. M. Manoj, S. K. Gade, L. Mathew, Cytochrome P450 reductase: a harbinger of diffusible reduced oxygen species. PLoS One 5: e13272 (2010).

19. A. Parashar, S. K. Gade, M. Potnuru, N. Madhavan, K. M. Manoj, The curious case of benzbromarone: insight into super-inhibition of cytochrome P450. PLoS One 9, e89967 (2014).

20. K. M. Manoj, S. K. Gade, A. Venkatachalam, D. A. Gideon, Electron transfer amongst flavo- and hemoproteins: diffusible species effect the relay processes, not protein-protein binding. RSC Adv. 6, 24121-24129 (2016).

21. K. M. Manoj, et al., Atypical profiles and modulations of heme-enzymes catalyzed outcomes by low amounts of diverse additives suggest diffusible radicals’ obligatory involvement in such redox reactions. Biochimie 125, 91111 (2016).

22. K. M. Manoj, A. Parashar, S. K. Gade, A. Venkatachalam, Functioning of microsomal cytochrome P450s: murburn concept explains the metabolism of xenobiotics in hepatocytes. Front. Pharmacol. 7, 161 (2016).

23. A. Parashar, D. A. Gideon, K. M. Manoj, Murburn Concept: a molecular explanation for hormetic and idiosyncratic dose responses. Dose Response 16, 1559325818774421 (2018).

24. K. M. Manoj, Debunking chemiosmosis and proposing murburn concept as the explanation for cellular respiration. Biomed. Rev. 28, 35-52 (2017).

25. K. M. Manoj, Aerobic respiration: criticism of the proton-centric explanation involving rotary ATP synthesis, chemiosmosis principle, proton pumps and electron transport chain. Biochem. Insights 11, 1178626418818442 (2018).

26. K. M. Manoj, D. A. Gideon, V. D. Jacob, Murburn scheme for mitochondrial thermogenesis. Biomed Rev. 29, 73-82 (2018).

27. K. M. Manoj, A. Parashar, V. D. Jacob, S. Ramasamy, Aerobic respiration: proof of concept for the murburn perspective. J. Biomol. Struct. Dyn. 37, 4524-4556 (2019).

28. K. M. Manoj, et al., Chemiosmotic and murburn explanations for aerobic respiration: predictive capabilities, structure-function correlations and chemico-physical logic. Arch. Biochem. Biophys. 676, 108128 (2019).

29. K. M. Manoj, V. Soman, Classical and murburn explanations for acute toxicity of cyanide in aerobic respiration: A personal perspective. Toxicology 432, 152369 (2020).

30. K. M. Manoj, Refutation of the cation-centric torsional ATP synthesis model and advocating murburn scheme for mitochondrial oxidative phosphorylation. Biophys. Chem. 257, 106278 (2020).

31. K. M. Manoj, Murburn concept: a paradigm shift in cellular metabolism and physiology. Biomol. Concepts 11, 7-22 (2020).

32. K. M. Manoj, The ubiquitous biochemical logic of murburn concept. Biomed. Rev. 29, 89-97 (2018).

33. K. Mailer, Superoxide radical as electron donor for oxidative phosphorylation of ADP. Biochem. Biophys. Res. Comm. 170, 59-64 (1990).

34. E. Tyszkiewicz, E. Roux, Role of the superoxide anion $\left(\mathrm{O}_{2}{ }^{-}\right)$and hydroxyl radical $(\mathrm{OH})$ in ATP synthesis obtained with spinach chloroplasts in darkness. In Progress in Photosynthesis Research (ed. Biggens, J.) Vol. III, 213-216. (Martinus Nijhoff Publishers, 1987).

35. D. J. Klionsky, W. S. A. Brusilow, R. D. Simoni, In vivo evidence for the role of the epsilon subunit as an inhibitor of the proton-translocating ATPase of Escherichia coli. J. Bacteriol. 160, 1055-1060 (1984).

36. A. Sturm, V. Mollard, A. Cozijinsen, C. D. Goodman, G. I. McFadden, Mitochondrial ATP synthase is dispensable in blood-stage Plasmodium berghei rodent malaria but essential in the mosquito phase. Proc. Natl. Acad. Sci. USA 112, 10216-10223 (2015).

37. D. A. GideonV. D. Jacob, K. M. Manoj, 2020: Murburn concept heralds a new era in cellular bioenergetics. Biomed. Rev. 30, 89-98 (2019).

38. N. M. Bazhin, Standard and transformed values of Gibbs energy formation for some radicals and ions involved in biochemical reactions. Arch. Biochem. Biophys. 686, 108282 (2020).

39. M. P. Murphy, How mitochondria produce reactive oxygen species. Biochem. J. 417, 1-13 (2009).

40. D. G. Nicholls, Mitochondrial membrane potential and aging. Aging Cell 3, 35-40 (2004).

41. C. P. Lee, Q. Gu, Y. Xiong, R. A. Mitchell, L. Ernster, P/O ratios reassessed: mitochondrial P/O ratios consistently exceed 1.5 with succinate and 2.5 with NAD-linked substrates. FASEB J. 10, 345-350 (1996). 
42. P. C. Hinkle, P/O ratios of mitochondrial oxidative phosphorylation. Biochim. Biophys. Acta Bioenerg. 1706, 111 (2005).

43. I. N. Watt, M. G. Montgomery, M. J. Runswick, A. G. Leslie, J. E.Walker, Bioenergetic cost of making an adenosine triphosphate molecule in animal mitochondria. Proc. Natl. Acad. Sci. USA, 107, 16823-16827 (2010).

44. M. R. de Oliveira, Vitamin A and retinoids as mitochondrial toxicants. Oxid. Med. Cell. Longev. 2015, 140267 (2015).

45. C. Farah, L. Y. M. Michel, J-L. Balligand, Nitric oxide signaling in cardiovascular health and disease. Nat. Rev. Cardiol. 15, 292-316 (2018).

46. R. Mittler, ROS are good. Trends Plant Sci. 22, 11-19 (2017).

47. X. Liu, et al., Acetate production from glucose and coupling to mitochondrial metabolism in mammals. Cell 175, 502-513 (2018).

48. D. A. Gideon, L. Hager, K. M. Manoj, The intriguing enhancement of chloroperoxidase mediated one-electron oxidations by azide, a known active-site ligand. Biochem. Biophys. Res. Commun. 415, 646-649 (2012).

49. A. Parashar, A. Venkatachalam, D. A. Gideon, K. M. Manoj, Cyanide does more to inhibit heme enzymes, than merely serving as an active-site ligand. Biochem. Biophys. Res. Commun. 455, 190-193 (2014).

50. K. M. Manoj, S. Ramasamy, A. Parashar, D. A. Gideon, V. Soman, V. D. Jacob, K. Pakshirajan, Acute toxicity of cyanide in aerobic respiration: Theoretical and experimental support for murburn explanation. Biomol. Concepts 11, 32-56 (2020).

51. EH40/2005 workplace exposure limits. $4^{\text {th }}$ ed. https://www.hse.gov.uk/pUbns/priced/eh40.pdf (2020).

52. W. Dilling, H. Cypionka, Aerobic respiration in sulfate-reducing bacteria. FEMS Microbiol. Lett. 71, 123-128 (1990).

53. M. Cohn, G. R. Drysdale, A study with O18 of adenosine triphosphate formation in oxidative phosphorylation. J. Biol. Chem. 216, 831-846 (1955).

54. G. D. Mironova, Metmyoglobin and peroxide compounds in mitochondria. In Mitochondria. Structure and functions in norm and pathology. pp 169-173. Nauka, Moscow (1971).

55. D. Yahalomi, S. D. Atkinson, M. Neuhof, E. S. Chang, H. Philippe, P. Cartwright, J. L. Bartholomew, D. Huchon, A cnidarians parasite of salmon (Myxozoa: Henneguya) lacks a mitochondrial genome. Proc. Natl. Acad. Sci. USA 117, 5358-5363 (2020).

56. F. Grein, A. R. Ramos, S. S. Venceslau, I. A. C. Pereira, Unifying concepts in anaerobic respiration: Insights from dissimilatory sulfur metabolism. Biochim. Biophys. Acta. Bioenergetics 1827, 145-160 (2013).

57. K. M. Manoj, Oxygenic photosynthesis: critiquing the standing explanations and proposing explorative solutions based in murburn concept. OSF Preprints, doi: 10.31219/osf.io/3mzfp (2019).

58. K. M. Manoj et al., Murburn precepts for the light reaction of oxygenic photosynthesis. OSF Preprints, doi: 10.31219/osf.io/95brg (2020).

59. G. Forti, P. Gerola, Inhibition of photosynthesis by azide and cyanide and the role of oxygen in photosynthesis. Plant Physiol. 59, 859-862 (1977).

60. J. Li, B. K. Burgess, J. L. Corbin, Nitrogenase reactivity: cyanide as substrate and inhibitor. Biochemistry 21, 4393-4402 (1982).

TABLES, FIGURES \& LEGENDS 
Table 1: Transformed $\Delta_{\mathrm{r}} G^{\prime 0}$ aq values and equilibrium constants of murburn scheme (1 through 13) and the erstwhile CRAS equations (A, B \& C) of mOxPhos.

\begin{tabular}{|c|c|c|c|}
\hline № & Reactions in physiological conditions & $\begin{array}{c}\Delta_{\mathrm{r}} G^{\prime 0}{ }_{\text {aq }} \\
(\mathrm{kJ} / \mathrm{mol})\end{array}$ & $K_{\text {eq. }}$ \\
\hline \multicolumn{4}{|c|}{ Murburn cascade initiated by Complex I } \\
\hline 1 & $\left(\mathrm{NADH}+\mathrm{H}^{+}\right)+\mathrm{O}_{2} \rightarrow \mathrm{NAD}^{+}+\mathrm{H}_{2} \mathrm{O}_{2}$ & -582.34 & $10^{102}$ \\
\hline 2 & $\mathrm{NADH}+2 \mathrm{O}_{2} \rightarrow \mathrm{NAD}^{+}+2^{*} \mathrm{O}_{2}^{-}+\mathrm{H}^{+}$ & -406.34 & $10^{71}$ \\
\hline 3 & $\mathrm{NADH}+2 \mathrm{O}_{2} \rightarrow \mathrm{NAD}^{+}+{ }^{*} \mathrm{O}_{2}{ }^{-}+{ }^{*} \mathrm{O}_{2} \mathrm{H}$ & -432.02 & $10^{76}$ \\
\hline 4 & $\begin{array}{l}\left(\mathrm{NADH}+\mathrm{H}^{+}\right)+\mathrm{ADPOH}+\mathrm{POH}+\mathrm{O}_{2} \rightarrow \\
\mathrm{NAD}+D^{+}+\mathrm{ADPOP}+\mathrm{H}_{2} \mathrm{O}+\mathrm{H}_{2} \mathrm{O}_{2}\end{array}$ & -546.31 & $10^{96}$ \\
\hline 5 & $\begin{array}{l}\left(\mathrm{NADH}+\mathrm{H}^{+}\right)+2 \mathrm{ADPOH}+2 \mathrm{POH}+\mathrm{O}_{2} \rightarrow \\
\mathrm{NAD}+ \\
+2 \mathrm{ADPOP}+2 \mathrm{H}_{2} \mathrm{O}+\mathrm{H}_{2} \mathrm{O}_{2}\end{array}$ & -510.28 & $10^{90}$ \\
\hline 6 & $\begin{array}{l}\left(\mathrm{NADH}+\mathrm{H}^{+}\right)+3 \mathrm{ADPOH}+3 \mathrm{POH}+\mathrm{O}_{2} \rightarrow \\
\mathrm{NAD}+3 \mathrm{ADPOP}+3 \mathrm{H}_{2} \mathrm{O}+\mathrm{H}_{2} \mathrm{O}_{2}\end{array}$ & -474.25 & $10^{83}$ \\
\hline 7 & $\begin{array}{l}\left(\mathrm{NADH}+\mathrm{H}^{+}\right)+4 \mathrm{ADPOH}+4 \mathrm{POH}+\mathrm{O}_{2} \rightarrow \\
\mathrm{NAD}^{+}+4 \mathrm{ADPOP}+4 \mathrm{H}_{2} \mathrm{O}+\mathrm{H}_{2} \mathrm{O}_{2}\end{array}$ & -438.38 & $10^{77}$ \\
\hline \multicolumn{4}{|c|}{ Murburn cascade initiated by Complex II } \\
\hline 8 & $\mathrm{FADH}_{2}+\mathrm{O}_{2} \rightarrow \mathrm{FAD}+\mathrm{H}_{2} \mathrm{O}_{2}$ & -111.55 & $10^{20}$ \\
\hline $9^{\#}$ & $\mathrm{FADH}_{2}+2 \mathrm{O}_{2} \rightarrow \mathrm{FAD}+2^{*} \mathrm{O}_{2} \mathrm{H}$ & 13.09 & $\sim 10^{-2}$ \\
\hline 10 & $\mathrm{FADH}_{2}+2 \mathrm{O}_{2} \rightarrow \mathrm{FAD}+2^{*} \mathrm{O}_{2}^{-}+2 \mathrm{H}^{+}$ & 64.45 & $10^{-11}$ \\
\hline 11 & $\begin{array}{l}\mathrm{FADH} H_{2}+\mathrm{ADPOH}+\mathrm{POH}+\mathrm{O}_{2} \rightarrow \\
\mathrm{FAD}+\mathrm{ADPOP}+\mathrm{H}_{2} \mathrm{O}+\mathrm{H}_{2} \mathrm{O}_{2}\end{array}$ & -75.52 & $10^{13}$ \\
\hline 12 & $\begin{array}{l}\mathrm{FADH}_{2}+2 \mathrm{ADPOH}+2 \mathrm{POH}+\mathrm{O}_{2} \rightarrow \\
\mathrm{FAD}+2 \mathrm{ADPOP}+2 \mathrm{H}_{2} \mathrm{O}+\mathrm{H}_{2} \mathrm{O}_{2}\end{array}$ & -39.49 & $10^{7}$ \\
\hline 13 & $\begin{array}{l}\mathrm{FADH}_{2}+3 \mathrm{ADPOH}+3 \mathrm{POH}+\mathrm{O}_{2} \rightarrow \\
\mathrm{FAD}+3 \mathrm{ADPOP}+3 \mathrm{H}_{2} \mathrm{O}+\mathrm{H}_{2} \mathrm{O}_{2}\end{array}$ & -3.46 & $10^{<1}$ \\
\hline \multicolumn{4}{|c|}{ Oxygen activation and ATP synthesis via the RCPE/CRAS scheme } \\
\hline A & $\left(\mathrm{NADH}+\mathrm{H}^{+}\right)+1 / 2 \mathrm{O}_{2} \rightarrow \mathrm{NAD}^{+}+\mathrm{H}_{2} \mathrm{O}$ & -677.3 & $10^{118}$ \\
\hline B & $\mathrm{FADH}_{2}+1 / 2 \mathrm{O}_{2} \rightarrow \mathrm{FAD}+\mathrm{H}_{2} \mathrm{O}$ & -206.51 & $10^{36}$ \\
\hline C & $\mathrm{ADPOH}+\mathrm{POH} \rightarrow \mathrm{ADPOP}+\mathrm{H}_{2} \mathrm{O}$ & 36.03 & $10^{-7}$ to $10^{-6}$ \\
\hline
\end{tabular}

\#This reaction would have much higher positive term $(65.7 \mathrm{~kJ} / \mathrm{mol})$ for the formation of $\left(\mathrm{FAD}+2 \mathrm{H}^{+}+2^{*} \mathrm{O}_{2}{ }^{-}\right)$. Therefore, the $\mathrm{FADH}_{2}$ reaction is primarily viable via the peroxidative path for ATP synthesis.

Murburn scheme: The superoxide (and peroxide thereafter) titer is practically replenished instantaneously via the thermodynamic pull exerted by sinking of electrons, owing to the presence of substrate, ADP/Pi. The presence of superoxide (generated primarily by Complex I) and peroxide (generated primarily by Complex II) ensure hydroxyl radical generation and sustenance in the murzone. (Uncouplers dissipate the DROS dynamics in murzone.) It is clearly discernible that the NADH reaction is more viable for charge separation and ATPsynthesis, as it uses both oxidative and peroxidative phosphorylation strategy. TMP is formed owing to the negatively charged DROS radicals and ions (and other species that accept electrons), which in turn, is due to the absence of compensating proton in the NADH molecule for one of the two electrons. The non-integral stoichiometric ratios are explained by the stochastic/statistical reaction paradigm of murburn model, wherein the final outcome is a mixture of several cycles. The lab to lab variability is explained by virtue of such a scheme of radical reactions. The oxidation of NADH gives much higher energy than what was earlier assumed ${ }^{4-7}$.

CRAS model: There exists no chemical connectivity of reactions between oxygen activation and ADP phosphorylation. A viable thermodynamic logic for "coupling of reactions A and B to C" is also lacking. Without involving DROS, two molecules of $\mathrm{NADH} / \mathrm{FADH}_{2}$ cannot viably react with one molecule of oxygen to form water. Earlier, reactions A \& B were supposed to respectively give -220 and $-150 \mathrm{~kJ} / \mathrm{mol}$ yield only (as calculated from the standard redox potentials) and this is corrected herewith. We have already demonstrated that equation C cannot explain physiological ATP concentrations with its low $K_{\mathrm{eq}}\left(\sim 10^{-7}\right)$. Therefore, the twoelectron CRAS scheme cannot explain the variable and non-integral stoichiometry of mOxPhos. 
Table 2. Energetics of some key reactions in the murburn model of mOxPhos.

\begin{tabular}{|c|c|c|c|c|c|c|c|}
\hline No. & \multicolumn{6}{|c|}{ Reactions in physiological conditions } & \multirow[t]{2}{*}{$\Delta_{\mathrm{r}} G^{{ }^{\prime o}}(\mathbf{k J} / \mathbf{m o l})$} \\
\hline & DROS & acking phosphate & & & & & \\
\hline 1 & $\mathrm{H}_{2} \mathrm{PO}_{4}^{-}$ & $+{ }^{*} \mathrm{OH} / \mathrm{O}_{2}^{*} /^{*} \mathrm{O}_{2} \mathrm{H}$ & $\rightarrow$ & ${ }^{*} \mathrm{HPO}_{4}^{-}$ & + & $\mathrm{H}_{2} \mathrm{O} / \mathrm{HO}_{2}^{-} / \mathrm{H}_{2} \mathrm{O}_{2}$ & $-32.2 / 132.3 / 93.2$ \\
\hline \multirow[t]{2}{*}{2} & $\mathrm{HPO}_{4}{ }^{2-}$ & $+{ }^{*} \mathrm{OH} /{ }^{*} \mathrm{O}_{2}^{-}$ & $\rightarrow$ & ${ }^{*} \mathrm{PO}_{4}{ }^{2-}$ & + & $\mathrm{H}_{2} \mathrm{O} / \mathrm{HO}_{2}^{-}$ & $151.9 / 316.4$ \\
\hline & \multicolumn{7}{|c|}{ Redox cycling of quinone } \\
\hline 3 & $Q$ & $+e^{-}$ & $\rightarrow$ & $Q^{*-}$ & & & -246.6 \\
\hline 4 & ${ }^{*} \mathrm{Q}^{-}$ & $+{ }^{*} \mathrm{O}_{2}^{-}\left(+2 \mathrm{H}^{+}\right)$ & $\rightarrow$ & $\mathrm{QH}_{2}$ & + & $\mathrm{O}_{2}$ & -118.4 \\
\hline 5 & ${ }^{*} \mathrm{Q}^{-}$ & $+{ }^{*} \mathrm{O}_{2}^{-}\left(+\mathrm{xH}^{+}\right)$ & $\rightarrow$ & $\mathrm{Q}$ & + & $\mathrm{HO}_{2}^{-} / \mathrm{H}_{2} \mathrm{O}_{2}$ & $-114.2 /-178.9$ \\
\hline 6 & ${ }^{*} \mathrm{Q}^{-}$ & $+\quad{ }^{*} \mathrm{O}_{2} \mathrm{H}\left(+\mathrm{H}^{+}\right)$ & $\rightarrow$ & $\mathrm{QH}_{2}$ & + & $\mathrm{O}_{2}$ & -92.7 \\
\hline 7 & ${ }^{*} \mathrm{Q}^{-}$ & $+{ }^{*} \mathrm{O}_{2} \mathrm{H}\left(+\mathrm{H}^{+}\right)$ & $\rightarrow$ & $Q$ & + & $\mathrm{HO}_{2}^{-} / \mathrm{H}_{2} \mathrm{O}_{2}$ & $-88.5 /-153.3$ \\
\hline 8 & ${ }^{*} \mathrm{Q}^{-}$ & $+{ }^{3} \mathrm{O}_{2} /{ }^{1} \mathrm{O}_{2}$ & $\rightarrow$ & Q & + & ${ }^{*} \mathrm{O}_{2}^{-}$ & $-2.9 /-96.2$ \\
\hline 9 & $\mathrm{QH}_{2}$ & ${ }^{1} \mathrm{O}_{2}$ & $\rightarrow$ & $Q^{*-}$ & + & ${ }^{*} \mathrm{O}_{2} \mathrm{H}\left(+\mathrm{H}^{+}\right)$ & -0.5 \\
\hline \multirow[t]{2}{*}{10} & $\mathrm{QH}_{2}$ & $+{ }^{3} \mathrm{O}_{2} /{ }^{1} \mathrm{O}_{2}$ & $\rightarrow$ & Q & + & $\mathrm{H}_{2} \mathrm{O}_{2}$ & $-60.5 /-153.8$ \\
\hline & \multicolumn{7}{|c|}{ Protonation } \\
\hline 11 & $\mathrm{H}^{+}$ & $\mathrm{OH}^{-}$ & $\rightarrow$ & $\mathrm{H}_{2} \mathrm{O}$ & & & -79.1 \\
\hline 12 & $\mathrm{H}^{+}$ & $\mathrm{HO}_{2}^{-}$ & $\rightarrow$ & $\mathrm{H}_{2} \mathrm{O}_{2}$ & & & -64.8 \\
\hline 13 & $\mathrm{H}^{+}$ & ${ }^{*} \mathrm{O}^{-}$ & $\rightarrow$ & ${ }^{*} \mathrm{OH}$ & & & -64.2 \\
\hline \multirow[t]{2}{*}{14} & $\mathrm{H}^{+}$ & ${ }^{*} \mathrm{O}_{2}^{-}$ & $\rightarrow$ & ${ }^{*} \mathrm{O}_{2} \mathrm{H}$ & & & -25.7 \\
\hline & \multicolumn{7}{|c|}{ Comparison with other reactions } \\
\hline A & $\mathrm{NH}_{3}$ & ${ }^{*} \mathrm{OH} / \mathrm{O}_{2}^{*} /{ }^{*} \mathrm{O}_{2} \mathrm{H}$ & $\rightarrow$ & ${ }^{*} \mathrm{NH}_{2}$ & + & $\mathrm{H}_{2} \mathrm{O} / \mathrm{HO}_{2}^{-} / \mathrm{H}_{2} \mathrm{O}_{2}$ & $-35.8 / 128.8 / 89.7$ \\
\hline B & $2 \mathrm{QH}_{2}$ & $+\quad 2$ Cyt.c $\mathrm{c}_{\mathrm{ox}}$ & $\rightarrow$ & $\mathrm{Q}+\mathrm{QH}_{2}$ & + & 2Cyt. $c_{\text {red }} \mathrm{H}$ & -32.5 \\
\hline
\end{tabular}

Equations 1 \& 2 show that the protonated state of phosphate is very crucial for enabling the facile generation of phosphate-centered radicals. DROS attack on monobasic phosphate can be compared to the former's reaction with ammonia (A). Some reactions of various species of quinone are shown (3-10) above the protonation energetics of some O-centered species (11-14). The erstwhile tetra-molecular equation of Complex III catalyzed reaction of reduced CoQ and cyt. $c$ is shown for comparison of energetic terms (B). Reactions like 4 and 6 of DROS and semiquinones lead to 2e sinks and reaction like 10 lead to recycling of quinols via peroxide. 
Table 3. Examples of some probable reactions of the murburn scheme of mOxPhos

\begin{tabular}{|c|c|c|c|c|c|c|c|}
\hline \multicolumn{7}{|c|}{ Reactions leading to radical quenching } & $\Delta_{\mathrm{r}} G^{\prime 0}(\mathrm{~kJ} / \mathrm{mol})$ \\
\hline $1 a$ & ADPOH & + & ${ }^{*} \mathrm{O}_{2} \mathrm{H}$ & $\rightarrow$ & $\mathrm{ADP}^{*}$ & $+\mathrm{H}_{2} \mathrm{O}+\mathrm{O}_{2}$ & \multirow{2}{*}{-217.0} \\
\hline $1 b$ & $\mathrm{POH}$ & + & *OH & $\rightarrow$ & $\mathrm{PO}^{*}$ & $+\mathrm{H}_{2} \mathrm{O}$ & \\
\hline $2 a$ & $\mathrm{ADPOH}$ & + & *OH & $\rightarrow$ & ADP* & $+\mathrm{H}_{2} \mathrm{O}_{2}$ & \multirow{2}{*}{-27.0} \\
\hline $2 b$ & $\mathrm{POH}$ & + & ${ }^{*} \mathrm{O}_{2} \mathrm{H}$ & $\rightarrow$ & PO $^{*}$ & $+\mathrm{H}_{2} \mathrm{O}_{2}$ & \\
\hline $3 a$ & $\mathrm{ADPOH}$ & + & ${ }^{*} \mathrm{O}_{2} \mathrm{H}$ & $\rightarrow$ & ADP* & $+\mathrm{H}_{2} \mathrm{O}+\mathrm{O}_{2}$ & \multirow{2}{*}{-91.5} \\
\hline $3 b$ & $\mathrm{POH}$ & + & ${ }^{*} \mathrm{O}_{2} \mathrm{H}$ & $\rightarrow$ & PO $^{*}$ & $+\mathrm{H}_{2} \mathrm{O}_{2}$ & \\
\hline $4 a$ & $\mathrm{ADPOH}$ & + & ${ }^{*} \mathrm{OH}$ & $\rightarrow$ & ADP* & $+\mathrm{H}_{2} \mathrm{O}_{2}$ & \multirow[b]{2}{*}{-149.6} \\
\hline $4 b$ & $\mathrm{POH}$ & + & ${ }^{*} \mathrm{OH}$ & $\rightarrow$ & $\mathrm{PO}^{*}$ & $+\mathrm{H}_{2} \mathrm{O}$ & \\
\hline $5 a$ & $\mathrm{ADPOH}$ & + & ${ }^{*} \mathrm{O}_{2} \mathrm{H}$ & $\rightarrow$ & ADPO* & $+\mathrm{H}_{2} \mathrm{O}_{2}$ & \multirow[b]{2}{*}{-27.0} \\
\hline $5 b$ & $\mathrm{POH}$ & + & ${ }^{*} \mathrm{OH}$ & $\rightarrow$ & $\mathrm{P}^{*}$ & $+\mathrm{H}_{2} \mathrm{O}_{2}$ & \\
\hline $6 a$ & $\mathrm{ADPOH}$ & + & * $\mathrm{OH}$ & $\rightarrow$ & ADPO $^{*}$ & $+\mathrm{H}_{2} \mathrm{O}$ & \multirow{2}{*}{-149.6} \\
\hline $6 b$ & $\mathrm{POH}$ & + & ${ }^{*} \mathrm{OH}$ & $\rightarrow$ & & $+\mathrm{H}_{2} \mathrm{O}_{2}$ & \\
\hline \multicolumn{8}{|c|}{ Reactions needing radical quenching } \\
\hline $7 a$ & ADPOH & + & ${ }^{*} \mathrm{O}_{2} \mathrm{H}$ & $\rightarrow$ & ADPO $^{*}$ & $+\mathrm{H}_{2} \mathrm{O}_{2}$ & \multirow{2}{*}{158.8} \\
\hline $7 b$ & $\mathrm{ADPO}^{*}$ & + & $\mathrm{POH}$ & $\rightarrow$ & ADPOP & $+{ }^{*} \mathrm{OH}$ & \\
\hline $8 a$ & $\mathrm{POH}$ & + & ${ }^{*} \mathrm{O}_{2} \mathrm{H}$ & $\rightarrow$ & $\mathrm{PO}^{*}$ & $+\mathrm{H}_{2} \mathrm{O}_{2}$ & \multirow{2}{*}{158.8} \\
\hline $8 b$ & $\mathrm{PO}^{*}$ & + & $\mathrm{ADPOH}$ & $\rightarrow$ & ADPOP & $+{ }^{*} \mathrm{OH}$ & \\
\hline 9a & $\mathrm{ADPOH}$ & + & *OH & $\rightarrow$ & ADPO $^{*}$ & $+\mathrm{H}_{2} \mathrm{O}$ & \multirow[b]{2}{*}{33.2} \\
\hline $9 b$ & $\mathrm{ADPO}^{*}$ & + & $\mathrm{POH}$ & $\rightarrow$ & ADPOP & $+\quad{ }^{*} \mathrm{OH}$ & \\
\hline $10 a$ & $\mathrm{POH}$ & + & * $\mathrm{OH}$ & $\rightarrow$ & $\mathrm{PO}^{*}$ & $+\mathrm{H}_{2} \mathrm{O}$ & \multirow{2}{*}{33.2} \\
\hline $10 \mathrm{~b}$ & $\mathrm{PO}^{*}$ & + & $\mathrm{ADPOH}$ & $\rightarrow$ & ADPOP & $+\quad \mathrm{OH}$ & \\
\hline 11a & $\mathrm{POH}$ & + & ${ }^{*} \mathrm{O}_{2} \mathrm{H}$ & $\rightarrow$ & $P^{*}$ & $+\mathrm{H}_{2} \mathrm{O}+\mathrm{O}_{2}$ & \multirow{2}{*}{269.9} \\
\hline $11 b$ & $\mathrm{P}^{*}$ & + & $\mathrm{ADPOH}$ & $\rightarrow$ & ADPOP & $+{ }^{*} \mathrm{H}$ & \\
\hline $12 a$ & $\mathrm{POH}$ & + & " $\mathrm{OH}$ & $\rightarrow$ & $P^{*}$ & $+\mathrm{H}_{2} \mathrm{O}_{2}$ & \multirow{2}{*}{334.4} \\
\hline $12 b$ & $P^{*}$ & + & $\mathrm{ADPOH}$ & $\rightarrow$ & ADPOP & $+{ }^{*} \mathrm{H}$ & \\
\hline \multicolumn{8}{|c|}{ ROS reacting among themselves } \\
\hline 13 & ${ }^{*} \mathrm{O}_{2} \mathrm{H}$ & + & $\mathrm{H}_{2} \mathrm{O}_{2}$ & $\rightarrow$ & $\mathrm{OH}$ & $+\mathrm{H}_{2} \mathrm{O}+\mathrm{O}_{2}$ & -64.5 \\
\hline 14 & ${ }^{*} \mathrm{O}_{2} \mathrm{H}$ & + & $\mathrm{O}_{2} \mathrm{H}$ & $\rightarrow$ & $\mathrm{H}_{2} \mathrm{O}_{2}$ & $+\mathrm{O}_{2}$ & -124.7 \\
\hline 15 & ${ }^{*} \mathrm{O}_{2} \mathrm{H}$ & + & ${ }^{*} \mathrm{OH}$ & $\rightarrow$ & $\mathrm{H}_{2} \mathrm{O}$ & $+\mathrm{O}_{2}$ & -250.1 \\
\hline 16 & ${ }^{*} \mathrm{OH}$ & + & $\mathrm{OH}^{-}$ & $\rightarrow$ & ${ }^{*}$ & $+\mathrm{H}_{2} \mathrm{O}$ & -14.9 \\
\hline 17 & ${ }^{*} \mathrm{OH}$ & + & $\mathrm{H}_{2} \mathrm{O}_{2}$ & $\rightarrow$ & ${ }^{*} \mathrm{O}_{2} \mathrm{H}$ & $+\mathrm{H}_{2} \mathrm{O}$ & -125.5 \\
\hline 18 & ${ }^{*} \mathrm{OH}$ & + & ${ }^{*} \mathrm{OH}$ & $\rightarrow$ & $\mathrm{H}_{2} \mathrm{O}_{2}$ & & -185.8 \\
\hline 19 & ${ }^{*} \mathrm{OH}$ & + & ${ }^{*} \mathrm{H}$ & $\rightarrow$ & $\mathrm{H}_{2} \mathrm{O}$ & & -492.3 \\
\hline 20 & ${ }^{*} \mathrm{O}_{2} \mathrm{H}$ & + & ${ }^{*} \mathrm{H}$ & $\rightarrow$ & $\mathrm{H}_{2} \mathrm{O}_{2}$ & & -361.4 \\
\hline
\end{tabular}

Only fully protonated DROS and ATP species are considered here for calculations and this is not an obligatory requisite in reality (as some adducts may not be fully protonated). The ATP synthesis reaction is minimally a two-step process. Each reaction is bimolecular and kinetically facile. From the thermodynamic perspective, reactions leading to water formation (via superoxide and peroxide) are more facile, forming the electron sinks. Addition of ADP+Pi to the reaction exerts a right-ward tug on the oxygen-superoxide equilibrium. The reactions 7 through 12 can be facile if the DROS released undergo subsequent quenching via a suitable reaction listed in equations 13 through 20. For example, reactions 9 and 10 would be viable if the hydroxyl radical formed reacted with a hydroxide ion, and the ${ }^{*} \mathrm{O}^{-}$formed thereafter got protonated. The reactions proposed above, in conjunction with ATP hydrolysis by Complex V, explain the pioneering observations that Mildred Cohn reported in the 1950s with ${ }_{18} \mathrm{O}$ labeling of phosphate and water. That is, our proposal agrees with Cohn's original deductions that ATP synthesis must go through at least two steps. [[Further explorative studies are necessary to nail the preferred routes of oxidative/peroxidative phosphorylation.]] We have shown that each beta monomer has two ADP/ATP binding sites, which is also corroborated by earlier experimental work ${ }^{27}$. Therefore, binding of 'esterified ATP' and 'ADP or ATP adducts' could lead to hydrolysis or protonated ATP's liberation from Complex $\mathrm{V}$ active site, as protons enter the matrix through $\mathrm{F}_{\mathrm{o}}$ module. (The last part of the outcome is in accordance to Boyer's proposals.) The details of Complex V's physiological role (with respect to the multiple binding loci) should be re-investigated under the light of murburn scheme. 
Table 4. The murburn mechanism of interaction of $\mathrm{HCN}$ and $\mathrm{H}_{2} \mathrm{~S}$ with mOxPhos system, demarcating the rationale for enhanced toxicity of cyanide.

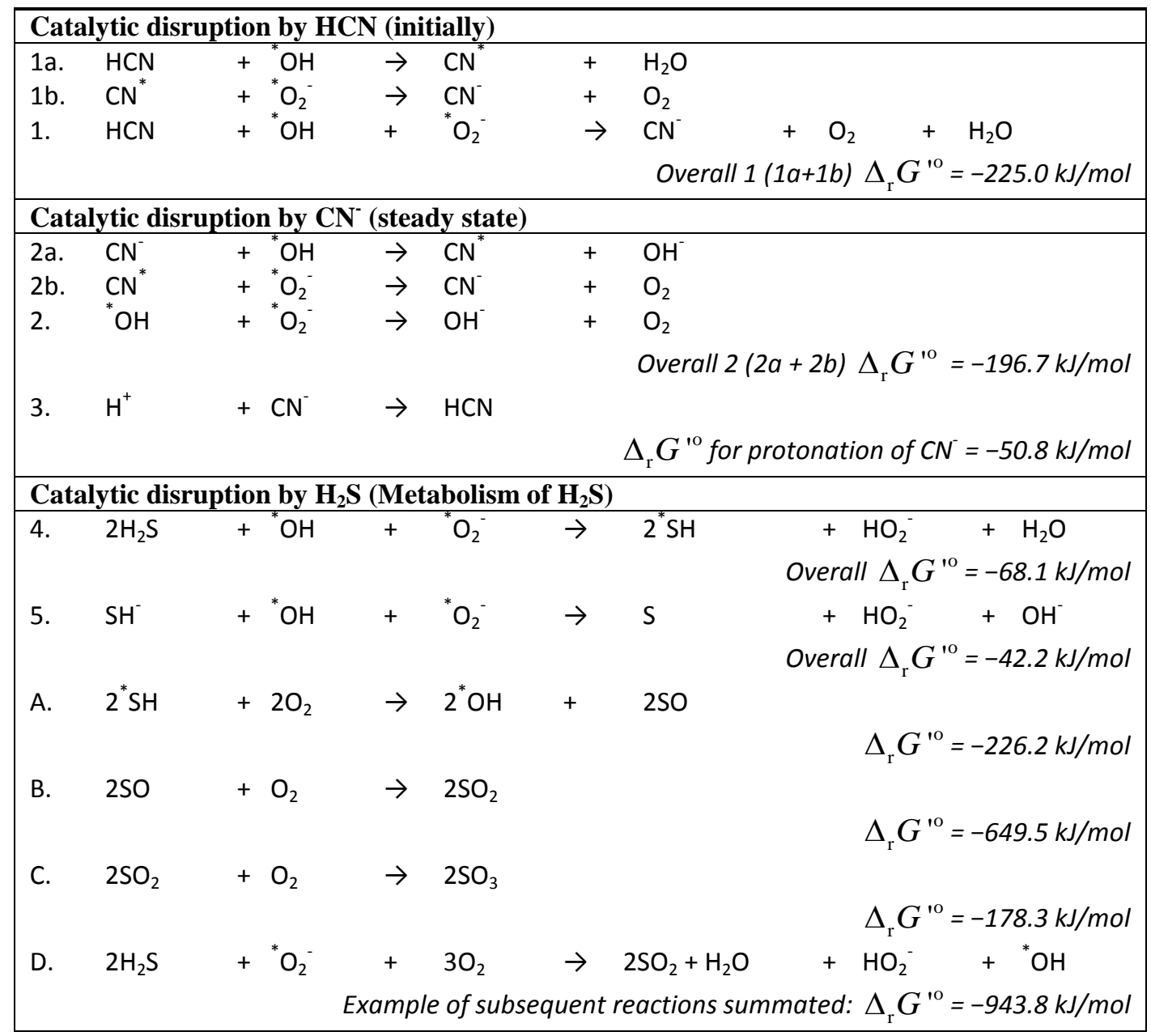




\section{FIGURE 1}

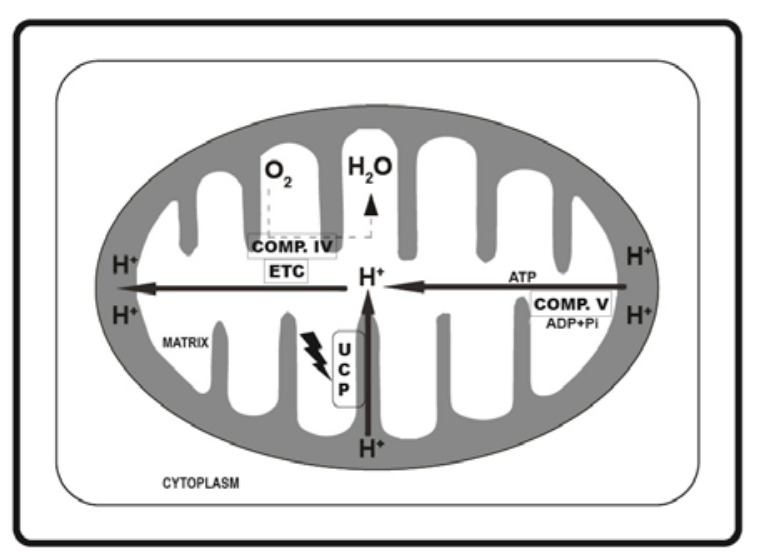

CHEMIOSMOSIS SCHEME

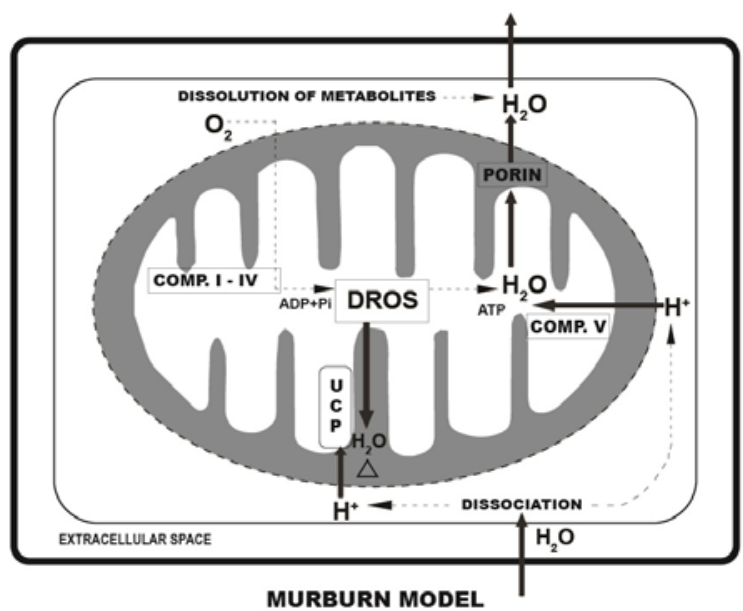

MURBURN MODEL

Figure 1: Comparison of the working (machine) logic of chemiosmotic and murburn models for aerobic respiration under isotonic conditions. The "closed pot, proton centric" chemiosmotic scheme requires both mitochondrial membranes to be selective and impervious to protons (so that TMP can result due to proton differentials), special oxygen delivery system to Complex IV alone, ordered arrangement of ETC on the membrane, and does not address mitochondria's need for externally sourced proton/water at all for the NADH reaction. Primarily, the key chemical respiratory reactions (phosphorylation) and thermogenesis occurring within mitochondria are based on a physical TMP (which exists between matrix and IMS owing to protons pumped out of matrix into IMS). That is, the matrix-ward movement/recycle of the 'pumped out and crowded protons' from the intermembrane space (IMS) gives ATP synthesis and heat. ETC proteins, Complex V and UCP deal with trans-membrane movement of protons. Such attributions do not give viable directionality or chemical reaction logic or holistic perspective in/for the system. The “continuously-fed, DROS centric" murburn model comprises of chemico-physical processes dependent on DROS dynamics, and whose outcomes affect the colligative properties of the mitochondrial microenvironment. The mitochondrial membranes need not be fastidiously selective (designated with broken lines), and this agrees with the mobility of oxygen and proton, and known experimental facts. The redox proteins can function independently and/or within supercomplex configurations (respirasomes). The membrane channels (porins and acyl carrier proteins or uncoupling proteins, ACP/UCP), porters and Complex $\mathrm{V}$ focus on different molecular or ionic species for their directional functioning. The mitochondrial redox proteins generate DROS (from $\mathrm{NADH}+\mathrm{O}_{2}$ ) at the IMM-matrix interface, which take finite time for neutralization in steady-state. This premise explains the TMP between the matrix and cytoplasm. The phosphorylation cum thermogenesis processes need protons as a 'limiting reactant' in steady state. The protons that diffuse through the mitochondrial membranes are taken up by reduced CoQ, which are not as mobile as phospholipids. Since porins are bi-directional, this 'continuously-fed' murburn model connects the chemical reactions of mitochondria with the directional homeostatic physiology of cells. [Dashed arrows are chemical reactions and continuous bold/straight arrows are transmembrane movements. Thunderbolt and triangle denoted near UCP stand for dissipation of potential and generation of heat, respectively.] 


\title{
Supplementary Information
}

\section{Murburn precepts for aerobic respiration and homeostasis}

\author{
Kelath Murali Manoj ${ }^{1 *} \&$ N. M. Bazhin ${ }^{2}$
}

*Corresponding author, ${ }^{1}$ Satyamjayatu: The Science \& Ethics Foundation, Snehatheeram, Kulappully, Shoranur-2 (PO), Kerala, India-679122. murman@satyamjayatu.com

2 Institute of Chemical Kinetics and Combustion Russian Academy of Sciences, Institutskaya 3, 630090 Russia. Novosibirsk State University, Pirogova 2, Novosibirsk, Russia. bazhin8999@kinetics.nsc.ru 
Table A. Compilation of Gibbs energy (kJ/mol) of formation of key ions, radicals and small molecules.

\begin{tabular}{|c|c|c|c|c|c|c|c|}
\hline № & Notation & Description & $\Delta_{\mathrm{f}} G^{\mathrm{o}}$ gas & $\Delta_{\mathrm{f}} G^{\prime \mathrm{o}}$ gas & $\Delta_{\mathrm{S}} G($ gas $\rightarrow \mathbf{a q})$ & $\Delta_{\mathrm{f}} G_{\mathrm{aq}}^{\mathrm{o}}$ & $\Delta_{\mathrm{f}} G^{\prime \mathrm{O}}{ }_{\mathrm{aq}}^{\#}$ \\
\hline 1 & ${ }^{3} \mathrm{O}_{2}$ & Oxygen (triplet) & 0 & 0 & 16.4 & 16.4 & 16.4 \\
\hline 2 & $\mathrm{H}_{2}$ & Hydrogen (molecule) & & & & & 99.13 \\
\hline 3 & $\mathrm{H}_{2} \mathrm{O}$ & Water & & & & -237.19 & -155.66 \\
\hline 4 & $\mathrm{H}_{2} \mathrm{O}_{2}$ & Hydrogen peroxide & & & & -134.03 & -52.5 \\
\hline 5 & $\mathrm{H}^{+}$ & Proton & 1516.99 & 1556.95 & -1104.5 & 412.49 & 452.45 \\
\hline 6 & $\mathrm{OH}^{-}$ & Hydroxide ion & -138.9 & -98.9 & -431.2 & -569.92 & -529.06 \\
\hline 7 & $\mathrm{HO}_{2}^{-}$ & Peroxide ion & -79.66 & -39.7 & -400.56 & -480.18 & -440.22 \\
\hline 8 & $\mathrm{SH}^{-}$ & Sulfanide or bisulfide ion & -106.11 & -66.15 & -293.82 & -399.93 & -359.97 \\
\hline 9 & $\mathrm{NADH}$ & Fully reduced NAD & & & & & 1120.09 \\
\hline 10 & NAD* & Partially oxidized NAD & & & & -321.79 & 738.11 \\
\hline 11 & $\mathrm{NAD}^{+}$ & Oxidized NAD (ion) & & & & 0 & 1059.11 \\
\hline 12 & $\mathrm{FMNH}_{2}$ & Fully reduced FMN & & & & & 813.97 \\
\hline 13 & $\mathrm{FMN}^{*-}$ & Partially oxidized FMN & & & & -416.74 & 355.36 \\
\hline 14 & FMN & Fully oxidized FMN & & & & 0 & 771.3 \\
\hline 15 & $\mathrm{FADH}_{2}$ & Fully reduced FAD & & & & & 1303.16 \\
\hline 16 & $\mathrm{FAD}^{*-}$ & Partially oxidized FAD & & & & -375.82 & 885.49 \\
\hline 17 & FAD & Fully oxidized FAD & & & & 0 & 1260.51 \\
\hline 18 & $Q$ & Oxidized Quinone & & & & 0 & 3668.9 \\
\hline 19 & ${ }^{*} \mathrm{Q}^{-}$ & Semiquinone (anion) & & & & -396.76 & 3272.95 \\
\hline 20 & $\mathrm{QH}_{2}$ & Reduced Quinone & & & & & 3660.55 \\
\hline 21 & $\mathrm{POH}$ & Inorganic phosphate (Pi) & & & & & -1059.49 \\
\hline 22 & ADPOH & ADP & & & & & -1424.79 \\
\hline 23 & ADPOP & ATP & & & & & -2292.5 \\
\hline 24 & 0 & Oxygen atom & 231.7 & 231.7 & 14.5 & 246.2 & 246.2 \\
\hline 25 & ${ }^{*} \mathrm{H}$ & Hydrogen atom/radical & 203.3 & 244.07 & 20.5 & 223.8 & 264.57 \\
\hline 26 & * OH & Hydroxyl radical & 34.2 & 74.97 & -8.4 & 25.8 & 66.57 \\
\hline 27 & $\mathrm{O}_{2} \mathrm{H}$ & Perhydroxyl radical & 22.6 & 63.37 & -19.1 & 3.5 & 44.27 \\
\hline 28 & $\mathrm{O}^{-}$ & Oxygen atomic radical & 91.86 & 91.05 & -413.0 & -320.91 & -321.72 \\
\hline 29 & ${ }^{*} \mathrm{O}_{2}^{-}$ & Superoxide radical & -44.1 & -44.91 & -382.5 & -381.69 & -382.5 \\
\hline 30 & * $\mathrm{sH}$ & Sulfanyl/mercapto radical & 113.3 & 154.07 & 5.71 & 119.01 & 159.78 \\
\hline 31 & ${ }^{*} \mathrm{NH}_{2}$ & Amino radical & 194.6 & 276.13 & -6.7 & 187.9 & 269.43 \\
\hline 32 & ${ }^{*} \mathrm{CH}_{3}$ & Methyl radical & 147.9 & 270.2 & 12.1 & 160.0 & 282.3 \\
\hline 33 & $\mathrm{HCN}$ & Hydrogen cyanide & 124.7 & 165.47 & -5.61 & 119.09 & 159.86 \\
\hline 34 & $\mathrm{CN}^{*}$ & Cyanyl radical & 405 & 405 & -5.61 & 399.39 & 399.39 \\
\hline 35 & $\mathrm{CN}^{-}$ & Cyanide ion & & & & -241.02 & -241.83 \\
\hline 36 & $\mathrm{H}_{2} \mathrm{~S}$ & Hydrogen sulfide & -33.4 & 48.13 & 5.71 & -27.69 & 53.84 \\
\hline 37 & $S$ & Sulfur (atom) & 236.69 & 236.69 & 14.5 & 251.2 & 251.2 \\
\hline 38 & $\mathrm{~S}_{2}$ & Disulfur (molecule) & 79.68 & 79.68 & 16.4 & 96.08 & 96.08 \\
\hline 39 & ${ }^{*} \mathrm{~S}_{2}^{-}$ & Disulfur anion radical & -82.13 & -82.94 & -337.8 & -419.93 & -420.74 \\
\hline 40 & SO & Sulfur monoxide & -19.9 & -19.9 & 16.4 & -3.5 & -3.5 \\
\hline 41 & $\mathrm{SO}_{2}$ & Sulfur dioxide & -300.1 & -300.1 & -19.93 & -320.03 & -320.03 \\
\hline 42 & $\mathrm{SO}_{3}$ & Sulfur trioxide & -371.1 & -371.1 & -29.90 & -401.0 & $-401^{\$}$ \\
\hline 43 & ${ }^{1} \mathrm{O}_{2}$ & Oxygen (singlet) & 93.27 & 93.27 & 16.4 & 109.67 & $109.67^{5}$ \\
\hline 44 & $\mathrm{e}^{-}$ & Electron (aquated) & 0 & -0.81 & -148.53 & -148.53 & $-149.34^{\$}$ \\
\hline 45 & $\mathrm{CH}_{4}$ & Methane & -50.72 & 112.35 & 16.39 & -34.33 & 128.73 \\
\hline 46 & $\mathrm{NH}_{3}$ & Ammonia & -16.4 & 105.9 & & -26.50 & 82.93 \\
\hline 47 & $\mathrm{H}_{2} \mathrm{PO}_{4}^{-}$ & Dihydrogen phosphate & & & & -1137.30 & -1056.58 \\
\hline 48 & $\mathrm{HPO}_{4}^{2-}$ & Hydrogen phosphate & & & & -1096.10 & -1058.52 \\
\hline 49 & ${ }^{*} \mathrm{HPO}_{4}^{-}$ & Hyd. phosphate radical & & & & -906.53 & -866.57 \\
\hline 50 & ${ }^{*} \mathrm{PO}_{4}^{2-}$ & Phosphate radical & & & & -681.2 & -684.44 \\
\hline
\end{tabular}


Details of calculation of the hitherto unreported $\Delta_{\mathrm{f}} G^{\prime \mathrm{o}}$ aq values (42-44)

\section{2. $\mathrm{SO}_{3}$}

$\Delta_{\mathrm{f}} G^{\mathrm{o}}\left(\mathrm{SO}_{\text {3gas }}\right)=-371.1 \mathrm{~kJ} / \mathrm{mol}$. (Handbook)

$\Delta_{\mathrm{f}} G^{\prime \mathrm{o}}\left(\mathrm{SO}_{3 \text { gas }}\right)=-371.1 \mathrm{~kJ} / \mathrm{mol}$

Gibbs function change for solubility $\mathrm{SO}_{2}$ is $-19.93 \mathrm{~kJ} / \mathrm{mol}$. It is reasonable to accept that

$\Delta_{\mathrm{S}} G\left(\mathrm{SO}_{3}\right)=3 / 2 \Delta_{\mathrm{S}} G\left(\mathrm{SO}_{2}\right)=3 / 2 \cdot(-19.93)=-29.90 \mathrm{~kJ} / \mathrm{mol}$. Hence

$\Delta_{\mathrm{f}} G^{\mathrm{o}}\left(\mathrm{SO}_{3 \mathrm{aq}}\right)=-401 \mathrm{~kJ} / \mathrm{mol}$ and

$\Delta_{\mathrm{f}} G^{\prime \mathrm{o}}\left(\mathrm{SO}_{3 \mathrm{aq}}\right)=-401 \mathrm{~kJ} / \mathrm{mol}$

\section{3. ${ }^{1} \mathrm{O}_{2}$}

Singlet oxygen $\mathrm{O}_{2}\left({ }^{1} \Delta_{g}\right)$ has an excitation energy $\left(E_{\mathrm{ex}}\right)$ of $0.977 \mathrm{eV}$, which is equivalent to $E_{\mathrm{ex}}=94.27 \mathrm{~kJ} / \mathrm{mol} . E_{\mathrm{ex}}$ refers to $0 \mathrm{~K}$.

In the gas phase, a excitation reaction takes place $\mathrm{O}_{2}\left({ }^{3} \sum \bar{g}\right) \rightarrow \mathrm{O}_{2}\left({ }^{1} \Delta_{g}\right)$.

with change in Gibbs function $\Delta_{\mathrm{r}} G^{\mathrm{o}}=\Delta_{\mathrm{r}} H^{\mathrm{o}}-T^{\mathrm{o}} \Delta_{\mathrm{r}} S^{\mathrm{o}}$.

$\Delta_{\mathrm{f}} G^{\mathrm{o}}\left(\mathrm{O}_{2}\left({ }^{3} \sum \bar{g}\right)\right)=0 \mathrm{~kJ} / \mathrm{mol}$. Hence $\Delta_{\mathrm{f}} G^{\mathrm{o}}\left(\mathrm{O}_{2}\left({ }^{1} \Delta_{g}\right)\right)=\Delta_{\mathrm{r}} G^{\mathrm{o}}$.

Now we need to calculate $\Delta_{\mathrm{r}} G^{\mathrm{o}}$.

$\Delta_{\mathrm{r}} H^{\mathrm{o}}=E_{\mathrm{ex}}+\Delta_{\mathrm{r}} C_{\mathrm{p}}^{\mathrm{o}} T^{\mathrm{o}}$. We can accept that $C_{\mathrm{p}}^{\mathrm{o}}\left[\mathrm{O}_{2}\left({ }^{3} \sum \bar{g}\right)\right] \approx C_{\mathrm{p}}^{\mathrm{o}}\left[\mathrm{O}_{2}\left({ }^{1} \Delta_{g}\right)\right]$ and

$\Delta_{\mathrm{r}} C_{\mathrm{p}}^{\mathrm{o}} \approx 0 \mathrm{~J} /(\mathrm{mol} \cdot \mathrm{K})$. Hence

$\Delta_{\mathrm{r}} H^{\mathrm{o}}=E_{\mathrm{ex}}$.

It can be further assumed that the translational entropies of both molecules are approximately equal. Then the difference in entropy remains due to the degeneracy of electronic states. Then

$\Delta_{\mathrm{r}} S^{\mathrm{o}}=R \ln 2-R \ln 3=-R \ln 1.5=-3.37 \mathrm{~J} /(\mathrm{mol} \cdot \mathrm{K})$. Hence

$\Delta_{\mathrm{r}} G^{\mathrm{o}}=\Delta_{\mathrm{r}} H^{\mathrm{o}}-T^{\mathrm{o}} \Delta_{\mathrm{r}} S^{\mathrm{o}}=E_{\mathrm{ex}}-R T^{\mathrm{o}} \ln 1.5=94.27-1.0=93.27 \mathrm{~kJ} / \mathrm{mol}$. Hence

$\Delta_{\mathrm{f}} G^{\mathrm{o}}\left(\mathrm{O}_{2 \mathrm{gas}}\left({ }^{1} \Delta_{g}\right)\right)=93.27 \mathrm{~kJ} / \mathrm{mol}$

We assume further that the Gibbs function of oxygen solvation is independent of the electronic state. Then $\Delta_{\mathrm{S}} G^{\mathrm{o}}\left(\mathrm{O}_{2}\left({ }^{1} \Delta_{g}\right)\right)=\Delta_{\mathrm{S}} G^{\mathrm{o}}\left(\mathrm{O}_{2}\left({ }^{3} \sum{ }_{g}^{-}\right)\right)=16.4 \mathrm{~kJ} / \mathrm{mol}$. Hence

$\Delta_{\mathrm{f}} G^{\mathrm{o}}\left(\mathrm{O}_{2 \mathrm{aq}}\left({ }^{1} \Delta_{g}\right)\right)=\Delta_{\mathrm{f}} G^{\mathrm{o}}\left(\mathrm{O}_{2 \mathrm{aq}}\left({ }^{1} \Delta_{g}\right)\right)=\Delta_{\mathrm{f}} G^{\mathrm{o}}\left(\mathrm{O}_{2 \mathrm{gas}}\left({ }^{1} \Delta_{g}\right)\right)+\Delta_{\mathrm{S}} G^{\mathrm{o}}\left(\mathrm{O}_{2}\left({ }^{1} \Delta_{g}\right)\right)=$ $93.27+16.4=109.67 \mathrm{~kJ} / \mathrm{mol}$.

44. $\mathrm{e}^{-}$ 
$\Delta_{\mathrm{f}} G^{\mathrm{o}}\left(\mathrm{e}_{\text {gas }}^{-}\right)=0 \mathrm{~kJ} / \mathrm{mol}$ and $\Delta_{\mathrm{f}} G^{\prime \mathrm{o}}\left(\mathrm{e}_{\text {gas }}^{-}\right)=-0.81 \mathrm{~kJ} / \mathrm{mol}$

The electron solvation energy is $-35.5 \mathrm{kcal} / \mathrm{mol}$ or $-148.53 \mathrm{~kJ} / \mathrm{mol}$ according toChang-Guo Zhan and David A. Dixon. The nature and absolute hydration free energy of the solvated electron in water. J. Phys. Chem. B 2003, 107, 4403-4417

Consequently, $\Delta_{\mathrm{f}} G^{\mathrm{o}}\left(\mathrm{e}_{\mathrm{aq}}^{-}\right)=\Delta_{\mathrm{S}} G^{\mathrm{o}}\left(\mathrm{e}_{\mathrm{aq}}^{-}\right)=-148.53 \mathrm{~kJ} / \mathrm{mol}$. Hence

$\Delta_{\mathrm{f}} G^{\prime \mathrm{o}}\left(\mathrm{e}_{\mathrm{aq}}^{-}\right)=-149.34 \mathrm{~kJ} / \mathrm{mol}$

Table B. Miscellaneous murburn reactions of mOxPhos

\begin{tabular}{|c|c|c|c|c|}
\hline № & Reaction in water $^{@}$ & $\begin{array}{c}\Delta_{\mathrm{r}} G^{\prime \mathrm{o}}{ }_{\mathrm{aq}}, \\
\mathrm{kJ} / \mathrm{mol}\end{array}$ & Eq. $K$ & Rate $\boldsymbol{k}^{\mathrm{q}}$ \\
\hline \multicolumn{5}{|c|}{ DROS dynamics with quinones ${ }^{f}$} \\
\hline 1 & $\mathrm{Q}+{ }^{*} \mathrm{OOH} \leftrightarrow{ }^{*} \mathrm{QH}+\mathrm{O}_{2}$ & nd & nd & $10^{3}-10^{9} \mathrm{M}^{-1} \mathrm{~s}^{-1}$ \\
\hline 2 & ${ }^{*} \mathrm{QH}+{ }^{*} \mathrm{OOH} \leftrightarrow \mathrm{QH}_{2}+\mathrm{O}_{2}$ & nd & nd & $\sim 10^{9} \mathrm{M}^{-1} \mathrm{~s}^{-1}$ \\
\hline \multicolumn{5}{|c|}{ DROS interactions amongst themselves } \\
\hline 3 & ${ }^{*} \mathrm{OOH}+\mathrm{H}_{2} \mathrm{O}_{2} \leftrightarrow{ }^{*} \mathrm{OH}+\mathrm{H}_{2} \mathrm{O}+\mathrm{O}_{2}$ & -64.5 & $10^{11}$ & $10^{3}-10^{7} M^{-1} s^{-1}-$ \\
\hline 4 & $\mathrm{OOH}+{ }^{*} \mathrm{OOH} \leftrightarrow \mathrm{H}_{2} \mathrm{O}_{2}+\mathrm{O}_{2}$ & -124.7 & $10^{22}$ & $10^{-1}-10^{8} \mathrm{M}^{-1} \mathrm{~s}^{-1}$ \\
\hline 5 & ${ }^{*} \mathrm{OOH}+{ }^{*} \mathrm{OH} \leftrightarrow \mathrm{H}_{2} \mathrm{O}+\mathrm{O}_{2}$ & -250.1 & $10^{44}$ & $\sim 10^{10} \mathrm{M}^{-1} \mathrm{~s}^{-1}$ \\
\hline 6 & ${ }^{*} \mathrm{OH}+{ }^{*} \mathrm{OH} \leftrightarrow \mathrm{H}_{2} \mathrm{O}_{2}$ & -185.8 & $10^{32}$ & $\sim 10^{10} \mathrm{M}^{-1} \mathrm{~s}^{-1}$ \\
\hline 7 & ${ }^{*} \mathrm{OH}+\mathrm{OH}^{-} \leftrightarrow \mathrm{H}_{2} \mathrm{O}+{ }^{*} \mathrm{O}^{-}$ & -14.9 & $10^{2.5}$ & $\sim 10^{10} \mathrm{M}^{-1} \mathrm{~s}^{-1}$ \\
\hline 8 & ${ }^{*} \mathrm{OH}+\mathrm{H}_{2} \mathrm{O}_{2} \leftrightarrow \mathrm{H}_{2} \mathrm{O}+{ }^{*} \mathrm{OOH}$ & -125.5 & $10^{22}$ & $\sim 10^{7} \mathrm{M}^{-1} \mathrm{~s}^{-1}$ \\
\hline 9 & $\mathrm{H}^{+}+\mathrm{OH}^{-} \leftrightarrow \mathrm{H}_{2} \mathrm{O}$ & -79.1 & $10^{14}$ & $\sim 10^{11} \mathrm{M}^{-1} \mathrm{~s}^{-1}$ \\
\hline \multicolumn{5}{|c|}{ DROS interactions with metal centers* } \\
\hline 10 & $\mathrm{Fe}^{3+}+{ }^{*} \mathrm{OOH} \leftrightarrow \mathrm{Fe}^{2+}+\mathrm{O}_{2}+\mathrm{H}^{+}$ & -61.4 & $10^{11}$ & $\sim 10^{5} \mathrm{M}^{-1} \mathrm{~s}^{-1}$ \\
\hline 11 & $\mathrm{Fe}^{2+}+{ }^{*} \mathrm{OOH}\left(+\mathrm{H}^{+}\right) \leftrightarrow \mathrm{Fe}^{3+}+\mathrm{HO}_{2}^{-}\left(\mathrm{H}_{2} \mathrm{O}_{2}\right)$ & -63.2 & $10^{11}$ & $\sim 10^{7} \mathrm{M}^{-1} \mathrm{~s}^{-1}$ \\
\hline 12 & $\mathrm{Fe}^{2+}+\mathrm{H}_{2} \mathrm{O}_{2} \leftrightarrow \mathrm{Fe}^{3+}+{ }^{*} \mathrm{OH}+\mathrm{OH}^{-}$ & 76.7 & $10^{-13}$ & $\sim 10^{3} \mathrm{M}^{-1} \mathrm{~s}^{-1}$ \\
\hline
\end{tabular}

@ For simplicity, proton availability has not been considered in the reactions. In that scenario, we would have lots of permutation/combination for the values, and thus complications in presentation. For example, simple ionic species like PO ${ }^{\circ}$ or $\mathrm{ADPO}^{-}$could be involved and the interaction scheme would involve radicals like $\mathrm{O}_{2}{ }^{*} /^{*} \mathrm{O}_{2} \mathrm{H},{ }^{*} \mathrm{Q}^{-} /^{*} \mathrm{QH}, \mathrm{NAD}{ }^{*} /{ }^{*} \mathrm{NADH}$, etc. Such a realistic scenario could potentially explain the $\mathrm{pH}$-based multiple optima issues originally observed in earlier literature of mOxPhos, as exemplified by Chance / Slater explorations in 1950s and the recent effects pointed out by KMM's group's works.

II These are consensus values from literature in second order terms. The rates of electron transfer (utilization of NADH or oxygen) and production of ATP in mitochondria is roughly in the order of $10^{2}$ to $10^{3}$ per second. This is agreeable and explainable with the murburn cascade. Equation 12, peroxide utilization by Complex IV, is contingent upon proton availability (to neutralize hydroxide ions) and is aided by cyt. $c$ mediated reduction of the Fe center, making this reaction as a crucial limiting step.

${ }^{£}$ These reactions are expected to be facile and subject to interfacial proton availability, explaining the effects of interfacial uncouplers. The reverse reaction may also be facilitated by Complex III, as quoted in literature. The uncatalyzed reverse reaction of semiquinone radical reacting with oxygen to give superoxide has a rate of $5 \times 10^{4} \mathrm{M}^{-1} \mathrm{~s}^{-1}$.

* Calculated with usual (standard) Gibbs function, as transformed values for $\mathrm{Fe}^{2+}$ aq and $\mathrm{Fe}^{3+}$ aq were not available. It can be seen that the reactions of both ferrous and ferric species with peroxide are not highly spontaneous, when seen thermodynamically. However, the enzymes like catalases/peroxidases/COX have evolved to lower the activation energy and experimentally viable kinetics is observed. Particularly, the reaction of ferrous species (11) is established to be a highly facile reaction in vitro and in situ. This explains the role of cytochrome $c$ 's reduction of COX.

\section{Details of calculations}



3)
$\stackrel{*}{\mathrm{OOH}}+\underset{44.3}{\mathrm{H}}-52.5$
$\Delta G-64.5 \quad \mathbf{K}=10^{11}$

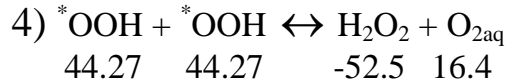
$\Delta G \mathbf{- 1 2 4 . 6 4} \quad \mathrm{K}=10^{22}$
5) ${ }^{*} \mathrm{OOH}+{ }^{*} \mathrm{OH} \leftrightarrow \mathrm{H}_{2} \mathrm{O}+\mathrm{O}_{2}$
$\Delta G=\mathbf{- 2 5 0 . 1} \quad \mathbf{K}=10^{44}$
$\begin{array}{llll}44.27 & 66.6 & -155.66 & 16.4\end{array}$
6) ${ }^{*} \mathrm{OH}+{ }^{*} \mathrm{OH} \leftrightarrow \mathrm{H}_{2} \mathrm{O}_{2}$
$\Delta G=\mathbf{- 1 8 5 . 6} \quad \mathbf{K}=10^{32}$
$66.6 \quad 66.6 \quad-52.5$
7) ${ }^{*} \mathrm{OH}+\mathrm{OH}^{-} \leftrightarrow \quad \mathrm{H}_{2} \mathrm{O}+{ }^{*} \mathrm{O}^{-}$
$66.6-529.06-155.66-321.72$
$\Delta G=\mathbf{- 1 4 . 9} \quad \mathrm{K}=10^{2.5}$
8) ${ }^{*} \mathrm{OH}+\mathrm{H}_{2} \mathrm{O}_{2} \leftrightarrow \mathrm{H}_{2} \mathrm{O}+{ }^{*} \mathrm{OOH}$
$\Delta G=\mathbf{- 1 2 5 . 5} \quad \mathbf{K}=10^{22}$
$66.6-52.5-155.66 \quad 44.27$
9) $\mathrm{H}^{+}+\mathrm{OH}^{-} \leftrightarrow \mathrm{H}_{2} \mathrm{O}$
$452.45-529.06-155,66$
$\Delta G=\mathbf{- 7 9 . 0 5} \quad \mathrm{K}=10^{14}$

(But we know from dissociation constant that 14 x $5.7=79.8$.)

(The difference is not big and this shows the accuracy of the calculation by transformed values.)
10) $\mathrm{Fe}^{3+}{ }_{\mathrm{aq}}+{ }^{*} \mathrm{OOH}_{\mathrm{aq}} \leftrightarrow \mathrm{Fe}^{2+}{ }_{\mathrm{aq}}+\mathrm{O}_{2 \mathrm{aq}}+\mathrm{H}^{+}{ }_{\mathrm{aq}} \quad \Delta G$
$\mathrm{Fe}^{2+}{ }_{\text {aq }}{ }^{+}+\mathrm{H}^{+}{ }_{\text {aq }} \quad \leftrightarrow \mathrm{Fe}^{3+}{ }_{\text {aq }}+1 / 2 \mathrm{H}_{2 \text { gas }} \quad \Delta G=0.77 \mathrm{~F}=74.29 \mathrm{~kJ} / \mathrm{mol}$

SUM

${ }^{*} \mathrm{OOH}_{\mathrm{aq}} \leftrightarrow \mathrm{O}_{2 \text { aq }}+1 / 2 \mathrm{H}_{2 \text { gas }}$

$3.5 \quad 16.4 \quad 0$

Hence

$\Delta G+74.29=12.9$ and

11) $\mathrm{Fe}^{2+}+{ }^{*} \mathrm{OOH}+\mathrm{H}^{+} \leftrightarrow \mathrm{Fe}^{3+}+\mathrm{H}_{2} \mathrm{O}_{2}$

$\mathrm{Fe}^{3+}{ }_{\mathrm{aq}}+1 / 2 \mathrm{H}_{2 \text { gas }} \leftrightarrow \mathrm{Fe}^{2+}{ }_{\text {aq }}{ }^{\circ}+\mathrm{H}^{+}{ }_{\text {aq }}$

SUM

${ }^{*} \mathrm{OOH}_{\text {aq }}+1 / 2 \mathrm{H}_{2 \text { gas }} \leftrightarrow \mathrm{H}_{2} \mathrm{O}_{2}$ aq

$3.52 \quad 0 \quad-134.03$

$\Delta G-74.29=-137.53$

12)

$$
\begin{aligned}
& \mathrm{Fe}^{2+}{ }_{\text {aq }}+\mathrm{H}_{2} \mathrm{O}_{2} \text { aq } \\
& \mathrm{Fe}^{3+}{ }_{\text {aq }}+1 / 2 \mathrm{Fe}_{2} \mathrm{H}_{2 \text { gas }} \leftrightarrow \mathrm{Fe}^{2+}{ }_{\text {aq }}+{ }^{*}{ }^{*} \mathrm{OH}_{\text {aq }}+\mathrm{H}^{+}{ }_{\text {aq }}^{-}
\end{aligned}
$$

SUM

$$
\mathrm{H}_{2} \mathrm{O}_{2 \text { aq }}+1 / 2 \mathrm{H}_{2 \text { gas }} \leftrightarrow{ }^{*} \mathrm{OH}_{\mathrm{aq}}+\mathrm{OH}^{-}{ }_{\mathrm{aq}}+\mathrm{H}^{+}{ }_{\mathrm{aq}}
$$$$
\begin{array}{lllll}
-134.03 & 0 & 25.8 & -569.92 & 412.49
\end{array}
$$

Hence

$\Delta G-74.29=2.4$ and

$$
\Delta G=12.9 \mathrm{~kJ} / \mathrm{mol}
$$

$\Delta G=-61.39$

$\mathrm{K}=10^{11}$

$\Delta G$

$-74.29$

$-137.53$

$\Delta G=\mathbf{- 6 3 . 2 4}$

$\mathrm{K}=10^{11}$

It is known that when $\mathrm{Fe}^{2+}$ aq is mixed with a solution of hydrogen peroxide (experimentally), there is an explosive evolution of oxygen. 
From the main text (Table 1), examples for calculation of oxygen activation reaction are-

Classical RCPE (error corrected by including the value protons)

$$
\begin{aligned}
& \left(\mathrm{NADH}+\mathrm{H}^{+}\right) / \mathrm{FADH}_{2}+1 / 2 \mathrm{O}_{2} \leftrightarrow \mathrm{NAD}^{+} / \mathrm{FAD}+\mathrm{H}_{2} \mathrm{O} \quad \Delta G=-677.0 /-206.5 \mathrm{~K}=10^{118} / 10^{36} \\
& \begin{array}{lllllll}
1120.09 & 452.45 & 1303.16 & 16.4 & 1059.11 & 1260.51 & -155.66
\end{array}
\end{aligned}
$$

Murburn model

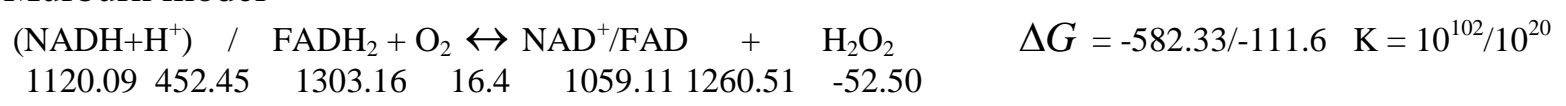

From the main text (Table 1), examples for murburn calculation of overall stoichiometry are-

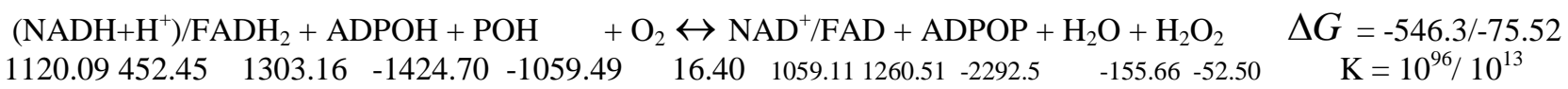

$\left(\mathrm{NADH}+\mathrm{H}^{+}\right) / \mathrm{FADH}_{2}+2 \mathrm{ADPOH}+2 \mathrm{POH}+\mathrm{O}_{2} \leftrightarrow \mathrm{NAD}+\mathrm{FAD}+2 \mathrm{ADPOP}+2 \mathrm{H}_{2} \mathrm{O}+\mathrm{H}_{2} \mathrm{O}_{2} \quad \Delta G=-510.27 /-39.49$

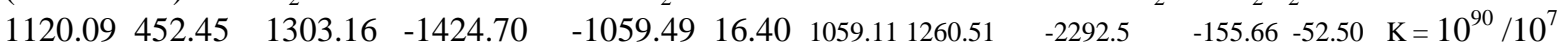

$\left(\mathrm{NADH}+\mathrm{H}^{+}\right) / \mathrm{FADH}_{2}+3 \mathrm{ADPOH}+3 \mathrm{POH}+\mathrm{O}_{2} \leftrightarrow \mathrm{NAD}+\mathrm{FAD}+3 \mathrm{ADPOP}+3 \mathrm{H}_{2} \mathrm{O}+\mathrm{H}_{2} \mathrm{O}_{2} \quad \Delta G=\quad-474.24 /-3.28$

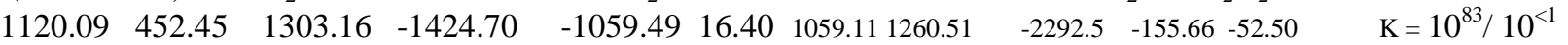

$\underline{\text { Generic murburn case for NADH }}$

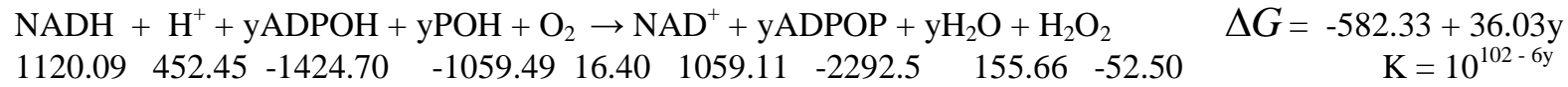

$\underline{\text { Generic murburn case for } \mathrm{FADH}_{2}}$

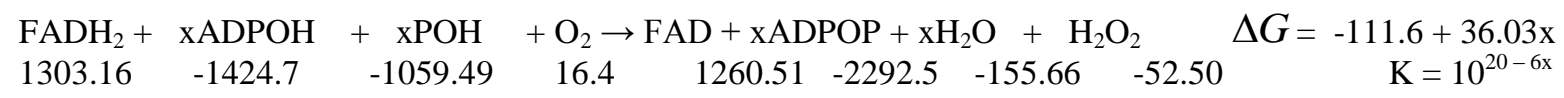

Comparison of murburn scheme with the RCPE/KMB model

Within the RCPE model, a minimum of 3 protons $\left(10^{-7} \mathrm{M}\right)$ to bind to the $\mathrm{F}_{\mathrm{o}}$ domain and $1 \mathrm{ADP}\left(10^{-4} \mathrm{M}\right)+1 \mathrm{Pi}\left(10^{-2} \mathrm{M}\right)$ to bind simultaneously at the $\mathrm{F}_{1}$ domain, and all this must happen to micromolar levels of Complex $\mathrm{V}$ distributed discretely at the phospholipid interface. The purported ATP synthesis via this multi-molecular mechano-electrical outcome would be an event of very low probability, particularly when seeing that mitochondria also have $\sim 10^{-3} \mathrm{M}$ ATP, which has $10^{7}$ fold higher affinity than ADP, for the same binding site of Complex V. Further, there is no connectivity between ETC and Complex V, and therefore, the enhanced consumption of $\mathrm{NADH} / \mathrm{O}_{2}$ (when $\mathrm{ADP}+\mathrm{Pi}$ is presented) is inexplicable in the RCPE paradigm. While the rotary function can be imaginable with a single molecule of ATP binding to the $F_{1}$ module triggering a motor movement (leading to inflow of protons), it is very difficult to envisage how proton binding at the $\mathrm{c}$ ring of $\mathrm{F}_{\mathrm{o}}$ module could induce a conformation change in the beta subunit. Since $\mathrm{pH}$ of mitochondria is usually retained at $\leq 7.4$, the ratio of $\mathrm{Pi}$ is $>4\left(\mathrm{HPO}_{4}{ }^{2-}: \mathrm{H}_{2} \mathrm{PO}_{4}{ }^{-}\right)$. Therefore, there is a definite need of protons even for the equilibrium driven $2 \mathrm{e}$ esterification reaction, which needs the formation of water as the leaving group (from the pentacovalent intermediate formed in transition state). As per the current belief advocated by Boyer, protons are not needed for ATP synthesis per se, but to release pre-formed ATP in the active site! Therefore, the Boyer model never claims to explain ATP synthesis at all! Regardless, what has been demonstrated with the single molecule experiment is the counter-clockwise movement of an actin filament (attached to gamma subunit, when the $\alpha \beta$ bulb is tethered on to a slide) during ATP hydrolysis. There is no evidence of a rotary function of the $\mathrm{F}_{\mathrm{o}}$ subunit in the physiological state, induced by proton movement. The existence of a trans-membrane potential (matrix versus cytoplasm) is an antithesis of Mitchellian proposal because it is known that inter-membrane space is in full equilibrium with cytoplasm. (As a consequence, TMP cannot build across matrix versus IMS!) Therefore, even if we overlook the non-availability of protons and the inapplicability of the single molecule experiment in physiological context, the proof afforded did not correlate to the claims of KMB model. 